NBER WORKING PAPER SERIES

\author{
NEW EVIDENCE ON \\ WORKPLACE EDUCATION
}

\author{
Alan Krueger \\ Cecilia Rouse \\ Working Paper No. 4831
NATIONAL BUREAU OF ECONOMIC RESEARCH
1050 Massachusetts Avenue
Cambridge, MA 02138
August 1994

We are grateful to the two companies and the community college that graciously provided us with data and patiently answered numerous questions. We are also indebted to the workers of the two companies who filled out our questionnaires. We are grateful to Herb Abelson, Kevin Hallock, Eric Hilfers, Dean Hyslop, Lisa Krueger, Mark Lopez, Jonathan Orszag, Paul Oyer, Jin Park, John Penrod, Xu Zhang, and especially Kim Neuman for excellent research assistance. Seminar participants at the University of Texas at Austin and Carnegie-Mellon provided valuable comments. We thank the Center for Economic Policy Studies at Princeton University for financial support. Unfortunately, the data used in this paper are confidential and may not be made available to other researchers. This paper is part of NBER's research program in Labor Studies. Any opinions expressed are those of the authors and not those of the National Bureau of Economic Research.

() 1994 by Alan Krueger and Cecilia Rouse. All rights reserved. Short sections of text, not to exceed two paragraphs, may be quoted without explicit permission provided that full credit, including ( ) notice, is given to the source. 


\title{
NEW EVIDENCE ON \\ WORKPLACE EDUCATION
}

\begin{abstract}
This paper presents an analysis of the impact of a workplace education program that was administered by a community college at two companies. One of the companies we study is in the manufacturing sector and the other is in the service sector. The analysis relies on longitudinal administrative data and cross-sectional survey data. We examine a broad range of outcome variables, including workers' eamings, performance awards, job attendance, and subjective performance measures. Our main finding is that the program had a small, positive impact on earnings at the manufacturing company, but an insignificant impact at the service company. We also find that the training program had a positive association with the incidence of job bids, upgrades, performance awards, and job attendance. At the manufacturing company, occupational courses, such as blue print reading, had the largest impact.
\end{abstract}

Alan Krueger

Industrial Relations Section

Firestone Library

Princeton University

Princeton, NJ 08544

and NBER
Cecilia Rouse

Woodrow Wilson School

Robertson Hall

Princeton University

Princeton, NJ 08544-2098

and NBER 
Although an extensive literature exists on the effectiveness of public sector job training, a much smaller literature exists on the impact of private sector job training on workers' wages, productivity and other employment outcomes. Heckman, et. al. (1993) attribute this difference to a lack of data and a greater ease in receiving funds for studies of public sector training. Nevertheless, several recent policy pronouncements call for the encouragement of more private sector training in the hope that training provided directly by employers will be effective. As an example, Burtless (1993) advocates a payroll tax to finance such training. Public policy regarding private sector training would be on much firmer ground if more were known about the return to investments in workplace training.

Most studies of public sector training generally find positive returns for female workers, but small and some times negative returns for male workers and youths (see LaLonde (1993) for a survey). On the other hand, the existing literature on private sector job training generally finds that such training programs have a positive effect on labor productivity. Bartel (1991) and Holzer, et. al. (1993) conclude that employer training increases labor productivity at the firm level. Using individual level data, Brown (1989), who uses the Panel Study of Income Dynamics, and Lillard and Tan (1986) and Bishop (1990), who use the Employment Opportunities Pilot Projects Surveys (EOPP), find that on-the-job training has a positive and significant effect on wages and reduces voluntary turnover. However, these studies rely on responses to questions that combine many diverse training programs, the relationship between the timing of the training and the current job is unclear, and the questions often refer only to entry level jobs. Furthermore, there is potential bias from nonrandom selection into training. Lynch (1992) uses the National Longitudinal Study of Youth (NLSY) and finds that off-job private training appears to increase wages significantly, while the positive effect of on-job training on wages disappears in firstdifferenced equations that eliminate any permanent individual effect on wages. Bartel (1994) 
analyzes a company database and finds that company training positively affects both wages and performance evaluations for professional employees. With all of these studies, it is unclear whether they provide relevant evidence on the types of private sector training programs currently being advocated.

In this paper, we study the effect of an employer-based education program on a variety of employment outcomes for individual employees. To perform this analysis we conducted a prospective study of a standardized job training program that was offered at two mid-sized companies (250-800 employees) in New Jersey. The workplace education program was administered and designed by a community college, as is common (Bassi (1994)), and subsidized by a grant from the federal government as part of the Workplace Literacy Program. A strength of our analysis is that we use data from administrative company records. We also supplement the company data with survey data that we collected from the employees. Our data set has several advantages over past data sets used to study private sector training. First, the key variable of interest, participation in the company training, is based on administrative records from the community college that organized and designed the training program. Thus, we have detailed information on the program as well as an understanding of the content of the training. Second, we have collected information on a rich set of employment outcomes, including wage growth, performance evaluations, and absenteeism. Finally, the training was focused on low-skilled, hourly workers, who have been hurt most by recent trends in the U.S. wage structure.

The fact that our data represent one training program and come from only two companies has both benefits and limitations. The obvious disadvantage is that our results are not necessarily applicable to other programs or to other companies; this must be kept in mind when considering the results. Another limitation is that the program ended in 
February, 1994. Thus, at this stage, we are unable to examine potential long-run effects of the training courses. On the other hand, the workers are likely more homogenous than those in national data sets and they face the same local labor market conditions. The estimates also apply to a standardized training program that is of current policy interest.

We find that participants in this training program were on average younger, had less seniority, and were more likely to be non-white and female than non-participants. Further, participants in both companies earned less per hour than comparable non-participants, suggesting negative selection into the program. On the other hand, in the manufacturing company, participants were more likely to have bid for posted jobs before the training started than were seemingly comparable non-participants. Overall, we find small effects of the program on individual outcomes. In the service company, we find no significant effect of the program on wage changes of participants relative to non-participants. We present limited evidence that participants were more likely to be nominated or win a performance award at the service company following training. Average wage growth for trainees in the manufacturing company is larger relative to non-trainees, and the effect is usually statistically significant at the $5 \%$ or $10 \%$ level. Further, trainees are more likely to bid for new jobs and to receive upgrades than comparable non-trainees. Much, if not all, of the overall increase in wages and job bidding appears to be due to "occupational" courses that provide skills that are valuable for specific jobs at this firm. Finally, the evidence suggests that workers have lower rates of absenteeism during the weeks in which they have classes.

\section{Background}

The training partnership between the companies we study and the community college began when the companies sought help from the college for on-site training for lower skilled 
workers. The companies believed that their lower skilled workers needed training if the companies were to remain competitive, and yet they did not have the in-house capability to provide such training. The program was designed by adult education specialists at the community college and subsidized by an 18 month grant from the federal government for $\$ 450,000$. The grant is part of the federal government's attempt to improve the workplace literacy of currently employed low-skilled workers. The training ran from October/November 1992 through February 1994, and consisted of courses provided on-site by teachers, hired specifically for the program, who specialize in adult education. Classes were held on-site and typically met twice per week for two hours and were taught in five 8-12 week sessions. Employees were paid their regular wages during class time.

Workers voluntarily signed-up for the classes, although they could only participate if their absence would not disrupt the flow of work, as classes met during the regular shifts. In our survey of the service employees, we inquired why they chose to take classes. Eighty percent of those who took at least one class cited a desire to improve or update their skills in general as one of the reasons for taking classes, $15 \%$ needed to know more about a particular subject, and $10 \%$ sought to learn enough to help their children or grandchildren at home. Only $10 \%$ of those taking classes circled "My supervisor made me do it" as one of the reasons. Among those who did not take any classes, just over $40 \%$ of those who were employed at the company last year claimed a lack of interest in the classes and only $12 \%$ claim to have been unable to "get off of the floor" as reasons for not participating. These results suggest that individuals taking the classes were more motivated than their nonparticipating co-workers.

A combined total of 480 workers attended the training classes. Eighty percent of the trainees enrolled in 1-3 classes for a total of 5800 hours of potential class time in the service 
company and 8400 hours of class time in the manufacturing. Workers in the two companies (combined) attended a total of over 12,500 actual class hours. The companies paid no direct costs (as the teachers' salaries, course materials, etc. were covered by the federal grant), however the indirect costs were large. In release time alone, the foregone cost of production amounted to almost $\$ 150,000$. The program director estimates the total indirect cost (which also includes the value of fringe benefits, $15 \%$ of the wages for 18 months for the employees of the companies who oversaw the training, and the rental cost of the room) to be about $\$ 300,000$. Thus, the program cost approximately $\$ 940$ per student, or $\$ 36$ per student class hour, and is about equivalent to the cost per trainee for programs sponsored by the Job Partnership Training Act (Bloom, et. al. (1993)). The total direct and indirect cost of the training program was about 4 percent of the average employee's compensation.

The content of the training was largely basic skills education that was, in part, custom tailored to these specific companies. Subjects ranged from reading, writing, math, and English as a Second Language, to more occupational courses such as blueprint math and blueprint reading. The program also included "mini" classes in subjects such as communication, stress reduction, and time management. Because the classes primarily taught general skills that would enhance productivity at other companies, a basic human capital model would predict that the employees bear the full cost of the classes. In principle, employers would have little or no incentive to pay for the training since employees could leave the company and receive the same pay for their new skills. On the one hand, since the employees in this program essentially bore none of the direct cost of the training (class attendance was on "company time") we might expect an increase in worker turnover, if their wages did not change. On the other hand, the directors of human resources, although aware of the possibility, were not overly concerned about inducing more turnover. In particular, the 
director at the manufacturing company noted that while skills such as blueprint reading were, in principle, valuable at other firms, the decline in manufacturing in the area reduced the portability of the skills, rendering the training more "specific" in nature.

In general, it does not appear that training participants had higher turnover in the months since the training began. In fact, at the manufacturing company $21 \%$ of those workers who were present just before the training started had left 18 months later; the comparable percentage is $18 \%$ among trainees. At the service company, only $10 \%$ of those workers who were present just before the training started had left 18 months later, and the turnover rate is roughly similar among both trainees and non-trainees. In the short run, based on these statistics, the training does not appear to have caused disproportionate turnover among the participants.

\section{Data}

The Manufacturing Company

Employment at the manufacturing company is highly cyclical, fluctuating between 500 and 700 production workers. All production workers were targeted for training. From job applications, we collected information on age, education, race, date of hire, and marital status. In addition, we recorded all jobs each employee had held while employed at the company. We have detailed information through November, 1993 and the company provided us with an update on the jobs held by employees as of February 1, 1994. Because the classes were held over five sessions and our data come from different sources, we illustrate the

1 In the manufacturing company, $70 \%$ of those who left did so because of "personal illness". Only about 3\% left due to "another job", "moved to another area", or were "absent for more than two weeks". Neither of these categories contain disproportionate shares of training participants. On the other hand, approximately $20 \%$ were laid-off or discharged (27 workers) of which only 3 had participated in training. 
timing of various outcome measures in relation to the training program in Figure 1 a.

Our first outcome measure is hourly wages. We recorded previous wage and job profiles within the company from the personnel files. The classes at the manufacturing company started in early November, 1992 and ended in February, 1994. Thus, we collected information on the wage in effect as of October, 1992 as a measure of the pre-training wage. Note that since the company is unionized, wage rates are attached to jobs. In some specifications we also include the wage in effect in July, 1991 to capture differential wage growth over the wage distribution. As stipulated by the union contract, job openings are posted and workers bid for them. The most senior qualified worker receives the job upgrade. Thus, another outcome we consider is the number of jobs for which an employee bids as well as the number of job upgrades received. Workers who receive training may bid for more jobs either due to increased skills that allow them to qualify for higher skilled jobs or because they perceive they are more qualified. Either way, the company gains by having a larger pool of applicants from which to choose. We collected both the total number of job bids and upgrades received from January 1992 through October 1992, as well as the number of job bids and upgrades received from November 1992 through October 1993 . We have the problem that the classes were still being held as of the dates of these outcome measures; however, all of the employees who were enrolled in classes in the fifth session had also taken classes in previous sessions.

Finally, representatives of the manufacturing company complained frequently about worker absenteeism and tardiness. Further, the community college organizers hypothesized that workers were more likely to come to work when they had class, which if true, would be a substantial benefit for this company. In order to test this hypothesis, we measured job absenteeism as the number of hours that an employee was absent from work, and for which 


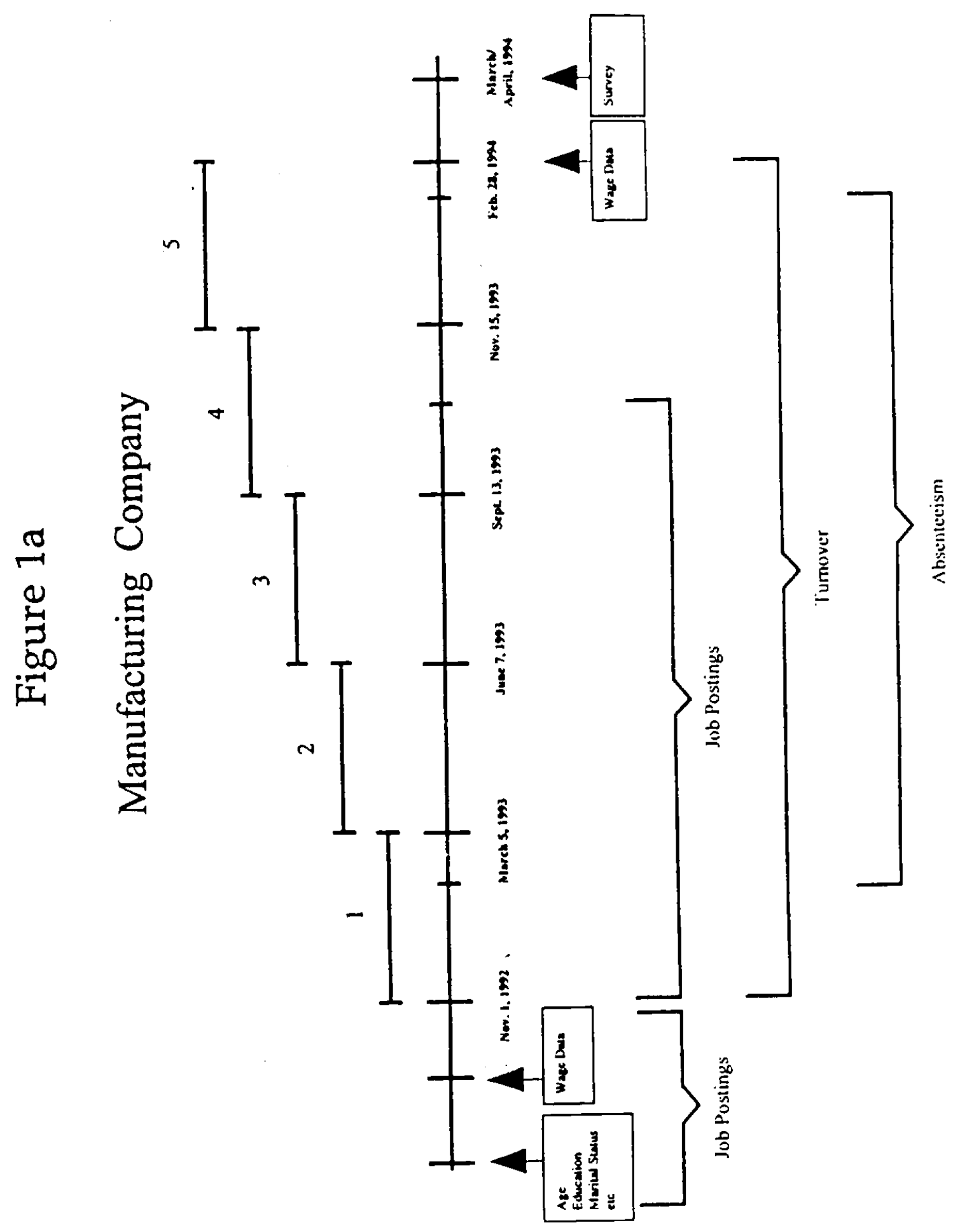


he was not paid, each week. ${ }^{2}$ Unpaid time also includes tardiness. For the manufacturing company, we have information on job absenteeism from the end of February, 1993 through the end of February, 1994.

We started with a sample of 729 production workers from the manufacturing company. In creating our analysis sample, however, we excluded 168 individuals who were not employed by the company on Feb. 1, 1994. In addition, we excluded 78 employees who were hired after October 31, 1992 (29 of whom left before February, 1994). Finally, we excluded nine apprentices. The apprenticeship program lasts 4 years and during that time, the apprentices are not paid according to the union wage schedule. Thus, our wage results are somewhat sensitive to which wage we assign them because the apprentices receive a large wage increase upon completion of the program. Given that the apprenticeship is another form of training and that participation in the community college program is unlikely to change the short-term trajectory of their wages, we chose to exclude them. ${ }^{3}$ Our final sample from the manufacturing company includes 503 workers.

\section{The Service Company}

The service company employs approximately 300 workers, of which 250 were targeted for training. We collected information on each worker's age, gender, race, education, marital status and date of hire from their job application forms. See Figure $1 \mathrm{~b}$ for a time line of the class sessions and our data. Following the analysis of the manufacturing company data, we collected information on the wage in effect as of November 1992 as a measure of the pre-

${ }^{2}$ There were 56 cases of more than 40 hours recorded as being unpaid for the week. This was likely due to clerical timing and we dropped these observations. Their exclusion had little effect on the results.

sesults including the apprentices can be obtained from the authors upon request. 


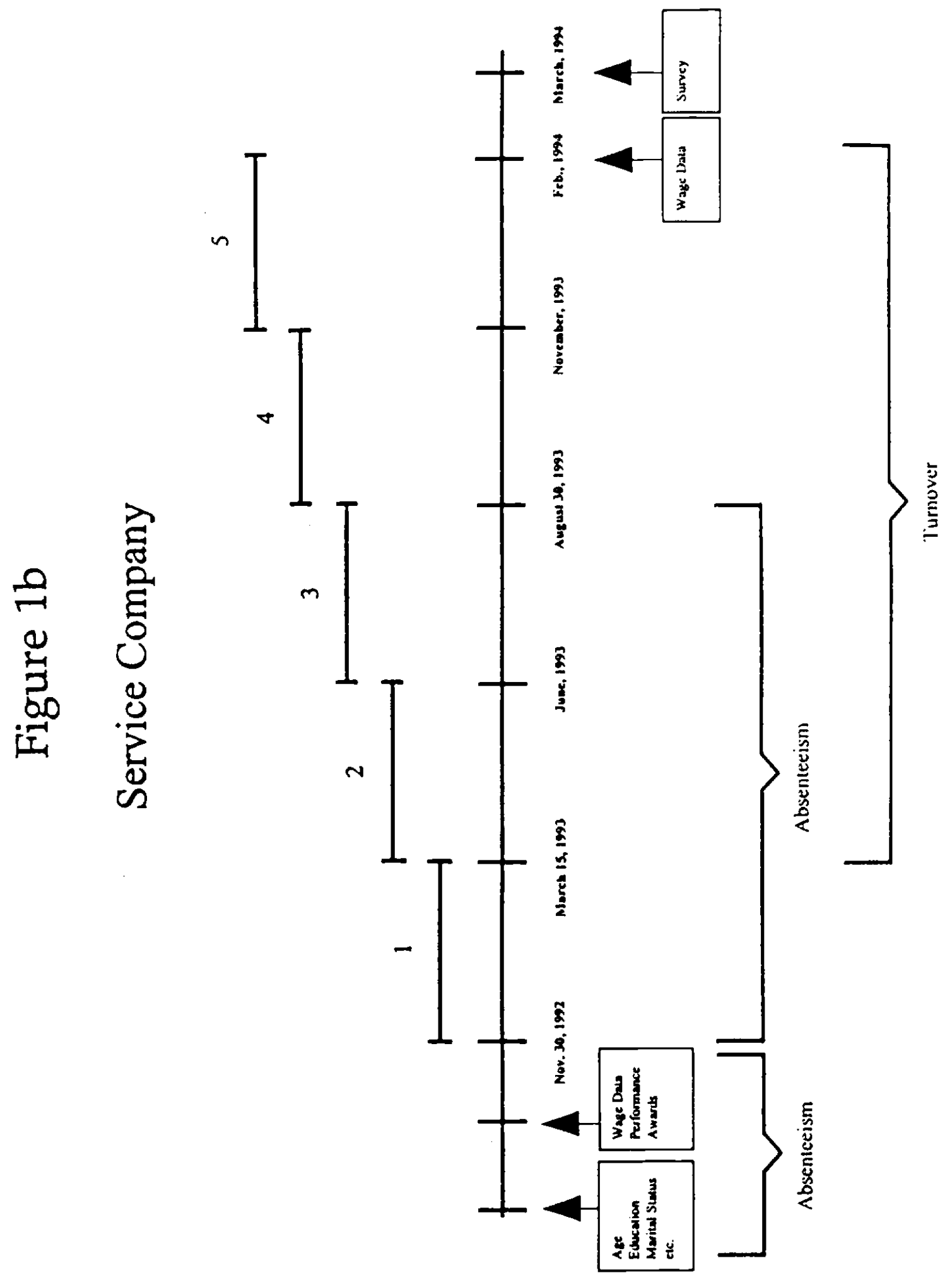


training wage. In some specifications, we also include a wage measure from September, 1991. The company has provided us with the hourly wage in effect in mid-January, 1994 as a measure of post-training wages. Although our post-training wage is not after the training program had completely ended, it does capture wages after participation for most. Ninety. five percent of those workers who took at least one class took their first class during the first four sessions, that is before November, 1993.

A second outcome we examine is the number of performance nominations and awards. The company has a monthly employee recognition program in which supervisors, co-workers, or customers nominate workers who have performed exceptionally well. There are individual as well as group level awards. The program has been in effect for several years and the exact details change periodically. Nevertheless, for the period in which we collect data, each month approximately 20-30 individuals (including entire work groups) are nominated for these prizes, and about 5 winners are selected by a rotating committee. All nominees attend a luncheon and winners of individual awards receive $\$ 25, \$ 50$, or $\$ 75$ to be determined by the committee. We collected the number of nominations and awards, both group and individual. that employees received from January, 1992 through November, 1992. We also recorded the number of nominations and awards for the period December, 1992 through February, 1994.

We treat nominations and awards as a reflection of worker productivity or motivation since those nominating an individual are asked to consider factors such as "extra effort," "team work," "quick action/short notice," "super quality effort," "problem solving," and "service excellence." Nominations require an explanation as to why the employee deserves the award, allowing us to observe the stated reasons for nomination. As a typical example, one group nomination reads,

Their special team-minded dedication and sacrifice over the past several months. During this time period, each of them gave up 
part of their weekends in order to complete [customer] printing backlogs. Around-the-clock weekend printing has consecutively been scheduled for almost every month. Some operators have worked as much as $20+$ hours.

An individual nomination describes,

Volunteering to come in on a Saturday to work overtime printing thousands of [customer] letters. In the middle of the printing, he noticed that there would not be enough stock to complete the run. He called [his manager] at home to see what could be done. He then went out of his way to look up on line the stock location (a task that he was not familiar with) and then made several trips to the 4th floor to bring down enough letterhead to finish the job. These tasks are not a requirement of his job, but he recognized the urgency in order to meet the customer deadline.

While it is possible that employees were nominated for the mere fact that they had attended the training program, rather than for any real productivity improvements, the recorded reasons for nominating employees suggest otherwise. The correlation between total number of performance award nominations and wages in 1994 is 0.35 , indicating that the award nominations are correlated with productivity.

Finally, we also measure the effect of the classes on worker absenteeism. Due to the form in which we could collect our data, this final outcome is measured differently in the service company than in the manufacturing company. In the service company, we calculated the fraction of the "regular" work week that the individual did not work. Thus, if there was one holiday day in a particular week, we counted the regular week as four days. If an individual took paid vacation, or had an absence due to an obligation such as jury duty, we also adjusted the "regular" week accordingly. The resulting variable ranges from zero to one, and we have information from January, 1992 through October, 1994.

Our final sample from the service company consists of 220 individuals. We eliminated 38 employees who started working at the company after November, 1992, 31 workers not targeted for the program (this eliminates 15 union workers plus another 16 sales 
representatives and upper management employees), and 38 employees who left the company before mid-January, 1994.

\section{A Comparison with the Current Population Survey}

Table 1 compares our samples with national samples from the annual merge file of the outgoing rotation groups of the Current Population Survey (CPS) for 1991. The CPS samples in columns (2) and (4) are from the same industry and exclude managerial, professional, technical and sales occupations to be comparable to our company samples. In our service company, the workers are slightly older and better paid, and there is a greater proportion female and Black than in the CPS sample, probably because the companies are located in New Jersey. On the other hand, the educational distributions are fairly similar. There is a smaller fraction of female employees and a larger proportion minority (Black and Hispanic) in the manufacturing company; the workers in our manufacturing company have slightly less education but are slightly better paid than the CPS sample. The smaller fraction ever-married in both companies is probably due to the fact that our information on this variable is not current since it is based on application forms. While our two companies cannot be representative of their industries because they are based in New Jersey, they are not obvious outliers either.

\section{Company Surveys}

To supplement our personnel and administrative data, we also conducted a survey of the employees in each company. (See Appendix A for a copy of the survey instrument.) The survey was conducted by asking employees to complete the questionnaire at work. At the manufacturing company the survey was conducted during the last 10-15 minutes of the 


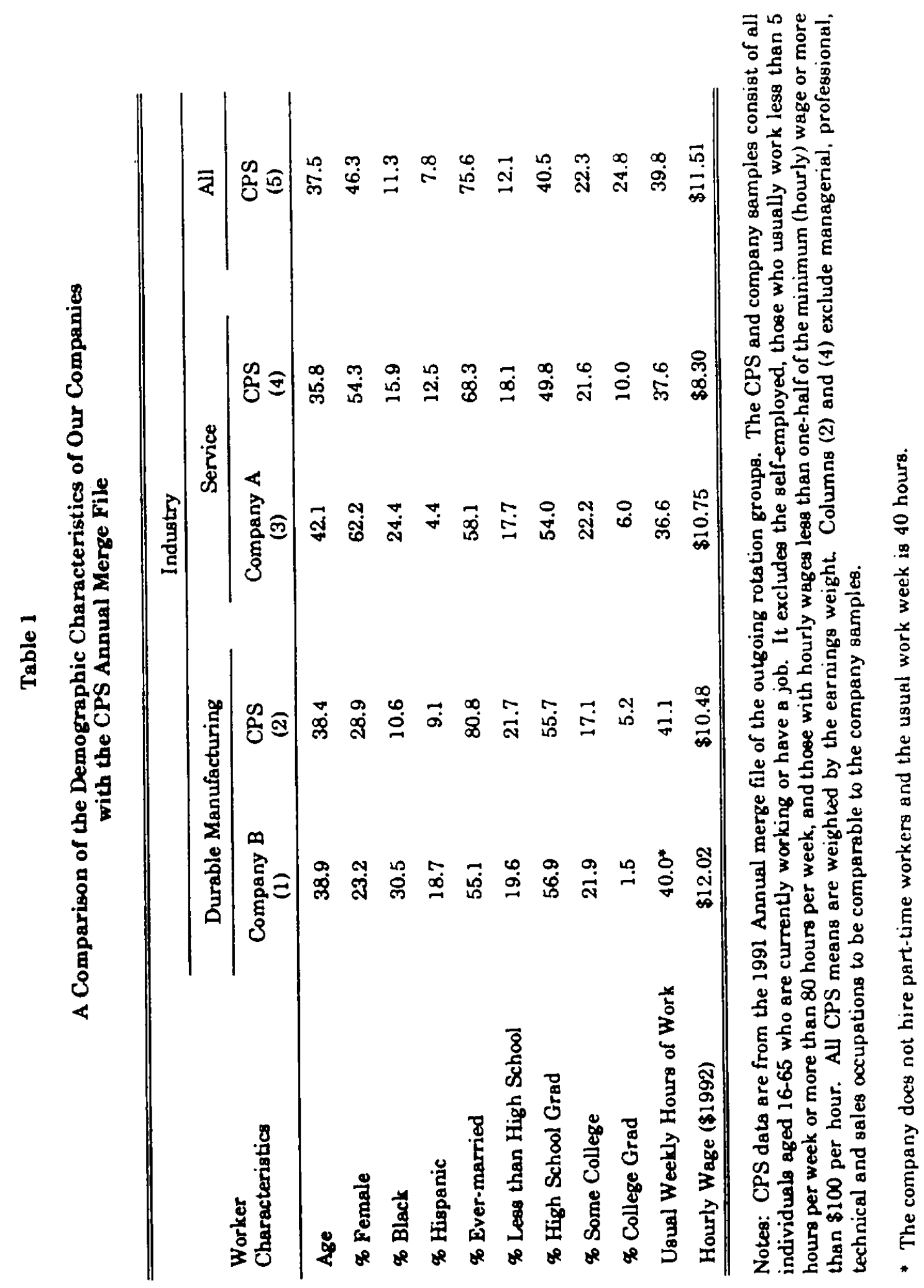


management's bi-monthly "information meeting," whereas representatives of the service company scheduled production workers to complete the survey at specified times. The survey was conducted from mid-March through early April, 1994. The response rate among those in attendance was very high, approximately $95 \%$.

The questionnaire elicited information on employees' attitudes towards their job, job performance relative to last year, interest in reading, educational aspirations for their children, as well as specific questions about why they did or did not participate in the training class. Further, we also asked workers for their martial status and education as our measures were from job applications and potentially out-of-date.

\section{Measuring Participation}

Our primary measure of participation in training is a dummy variable indicating whether an individual took at least one class in any of the five sessions. For the manufacturing company we also measure training as having taken at least one occupational class since these classes provided skills that would allow workers to become eligible for certain jobs within the company. We have experimented with other measures of participation such as the actual number of hours of class attended and a measure that weights participation by the months since the class (to reflect the fact that some individuals completed their classes in an early session while others were still enrolled in February, 1994). The results are fairly robust to alternative specifications.

For our analysis of subjective outcomes using the survey data from the service company, we use self-reported measures of training participation in order to maximize our sample size. To gauge the extent to which individuals correctly identified their training status in the survey data, we compared the self-reports of training to administrative records 
for the subset of the survey participants we could match with our survey sample. The results are reported below:

\section{Comparison of Self-reported and Actual Reports of Participation} Manufacturing Company:

(Frequencies are Reported in Cells)

\begin{tabular}{|l|cc|}
\hline & \multicolumn{2}{|c|}{ Self-Reported Participation } \\
Actual & Never Participated & Participated \\
Participation & & \\
\hline Never Participated & 127 & 31 \\
& $(46 \%)$ & $(11 \%)$ \\
Participated & 9 & 112 \\
& $(3 \%)$ & $(40 \%)$ \\
\hline
\end{tabular}

\section{Service Company:}

(Frequencies are Reported in Cells)

\begin{tabular}{|l|cc|}
\hline & \multicolumn{2}{|c|}{ Self-Reported Participation } \\
Actual & Never Participated & Participated \\
Participation & & \\
\hline Never Participated & 45 & 7 \\
& $(35 \%)$ & $(5 \%)$ \\
Participated & 3 & 75 \\
& $(2 \%)$ & $(58 \%)$ \\
\hline
\end{tabular}

Eighty-six percent of the manufacturing company employees correctly reported their training status, and 93 percent of service company employees correctly reported their training status. Interestingly, in both cases the more common error was for nontrainees to report having taken training. At the manufacturing company, $20 \%$ of nontrainees reported they took the training course, whereas the corresponding error rate for the service company is 
13\%. About $20 \%$ of the manufacturing employees and $10 \%$ of the service employees who responded that they took training in our survey did not take the training course according to the administrative records. The high error rate leads one to be concerned about the impact of measurement error in studies of the effectiveness of on-the-job training that are based solely on worker self-reports of training.

\section{Who Participates in Training?}

Tables $2 a$ and $2 b$ present the means and standard deviations of key variables for employees of the manufacturing and service companies, disaggregated by whether or not they participated in the training program. We measure training status by the administrative records here. Because the occupational courses seem to be particularly germane at the manufacturing company, we present estimates for workers who took at least one occupational training class as well. In both companies, the trainees tend to be younger, more likely to be male, more likely to be nonwhite, and better educated than the non-trainees. Given these characteristics, it is not surprising that the pre-training average hourly wage of the trainees is lower than that of the non-trainees.

In Table 3 we present probit estimates of participation equations for each company. The dependent variable equals 1 if the employee participated in training, and 0 otherwise. Derivatives of the probabilities at the mean values of the variables are reported along with the probit coefficients. Again, for the manufacturing company we treat all training courses and occupational training course separately.

First consider results for the manufacturing company. There is a statistically insignificant relationship between the incidence of training and tenure (p-value equals 0.27 ). Years of education have a positive and statistically significant effect on the incidence of 
Table 2a

Descriptive Statistics for Training Participants and Non-participants Manufaxturing Company

[Standard Deviation]

\begin{tabular}{|c|c|c|c|}
\hline \multirow{2}{*}{ 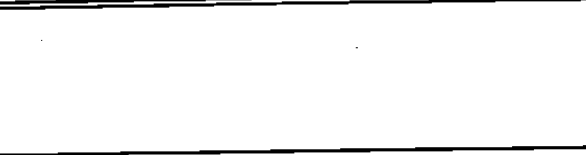 } & \multirow[b]{2}{*}{$\begin{array}{c}\text { Never } \\
\text { Participated }\end{array}$} & \multicolumn{2}{|c|}{ Ever Participated } \\
\hline & & $\begin{array}{l}\text { Any } \\
\text { Class }\end{array}$ & $\begin{array}{c}\text { Any } \\
\text { Occupational Class }\end{array}$ \\
\hline Age & $\begin{array}{c}40.2 \\
{[10.00]}\end{array}$ & $\begin{array}{l}38.9 \\
{[7.97]}\end{array}$ & $\begin{array}{l}37.5 \\
{[7.53]}\end{array}$ \\
\hline Female & $\begin{array}{c}0.17 \\
{[0.38]}\end{array}$ & $\begin{array}{c}0.26 \\
{[0.44]}\end{array}$ & $\begin{array}{c}0.17 \\
{[0.37]}\end{array}$ \\
\hline Non-white & $\begin{array}{c}0.43 \\
{[0.50]}\end{array}$ & $\begin{array}{c}0.49 \\
{[0.50]}\end{array}$ & $\begin{array}{c}0.52 \\
{[0.50]}\end{array}$ \\
\hline Married & $\begin{array}{c}0.57 \\
{[0.49]}\end{array}$ & $\begin{array}{c}0.66 \\
{[0.47]}\end{array}$ & $\begin{array}{c}0.62 \\
{[0.49]}\end{array}$ \\
\hline Years of Education & $\begin{array}{l}11.90 \\
{[1.34]}\end{array}$ & $\begin{array}{l}12.25 \\
{[1.27]}\end{array}$ & $\begin{array}{l}12.35 \\
{[1.32]}\end{array}$ \\
\hline Tenure (years)* & $\begin{array}{c}10.12 \\
{[7.24]}\end{array}$ & $\begin{array}{c}8.31 \\
{[5.36]}\end{array}$ & $\begin{array}{l}7.90 \\
{[5.09]}\end{array}$ \\
\hline Works 1st Shift (\%) & $\begin{array}{c}0.72 \\
{[0.45]}\end{array}$ & $\begin{array}{c}0.69 \\
{[0.46]}\end{array}$ & $\begin{array}{c}0.68 \\
{[0.47]}\end{array}$ \\
\hline Shift, missing & $\begin{array}{c}0.01 \\
{[0.12]}\end{array}$ & $\begin{array}{c}0.02 \\
{[0.13]}\end{array}$ & $\begin{array}{c}0.01 \\
{[0.11]}\end{array}$ \\
\hline Hourly Wage, Oct. 1992** & $\begin{array}{l}12.54 \\
{[1.05]}\end{array}$ & $\begin{array}{l}12.19 \\
{[0.52]}\end{array}$ & $\begin{array}{l}12.22 \\
{[0.43]}\end{array}$ \\
\hline No. of Job Postings Bid For, 1992 & $\begin{array}{c}0.35 \\
{[0.82]}\end{array}$ & $\begin{array}{c}0.59 \\
{[1.30]}\end{array}$ & $\begin{array}{c}0.75 \\
{[1.44]}\end{array}$ \\
\hline No. of Upgrades Received. 1992 & $\begin{array}{c}0.05 \\
{[0.23]}\end{array}$ & $\begin{array}{c}0.12 \\
{[0.35]}\end{array}$ & $\begin{array}{c}0.18 \\
{[0.41]}\end{array}$ \\
\hline Hourly Wage. Jan. 1994** & $\begin{array}{l}12.76 \\
{[1.01]}\end{array}$ & $\begin{array}{l}12.45 \\
{[0.53]}\end{array}$ & $\begin{array}{l}12.51 \\
{[0.45]}\end{array}$ \\
\hline No. of Job Postings Bid For, 1993 & $\begin{array}{c}0.33 \\
{[0.92]}\end{array}$ & $\begin{array}{c}0.71 \\
{[1.47]}\end{array}$ & $\begin{array}{c}1.11 \\
{[1.81]}\end{array}$ \\
\hline No. of Upgrades Received. 1993 & $\begin{array}{c}0.04 \\
{[0.23]}\end{array}$ & $\begin{array}{c}0.12 \\
{[0.34]}\end{array}$ & $\begin{array}{c}0.18 \\
{[0.41]}\end{array}$ \\
\hline Avg. No. of Unpaid Hours per Week. 1993 & $\begin{array}{c}1.92 \\
{[1.60]}\end{array}$ & $\begin{array}{c}1.64 \\
{[1.27]}\end{array}$ & $\begin{array}{c}1.68 \\
{[1.53]}\end{array}$ \\
\hline Total "Potential" Hours of Class Attended & & $\begin{array}{c}43.7 \\
{[31.4]}\end{array}$ & $\begin{array}{c}52.5 \\
{[32.0]}\end{array}$ \\
\hline Total "Actual" Hours of Class Attended & & $\begin{array}{c}35.5 \\
{[27.6]}\end{array}$ & $\begin{array}{c}43.3 \\
{[29.4]}\end{array}$ \\
\hline Took Any Occupational Classes & & $\begin{array}{c}0.50 \\
{[0.50]}\end{array}$ & \\
\hline No. of Observations & 324 & 179 & 90 \\
\hline
\end{tabular}

* Tenure is as of October. 1992.

** All wages are in 1993 dollars. 
Table 2b

Descriptive Statistics for Training Participants and Non-participants Service Company

[Standard Deviation]

\begin{tabular}{|c|c|c|}
\hline & Never Participated & Ever Participated \\
\hline Age & $\begin{array}{c}48.5 \\
{[15.0]}\end{array}$ & $\begin{array}{c}37.5 \\
{[11.1]}\end{array}$ \\
\hline Female & $\begin{array}{c}0.62 \\
{[0.49]}\end{array}$ & $\begin{array}{c}0.70 \\
{[0.46]}\end{array}$ \\
\hline Non-white & $\begin{array}{c}0.28 \\
{[0.45]}\end{array}$ & $\begin{array}{c}0.33 \\
{[0.47]}\end{array}$ \\
\hline Married & $\begin{array}{c}0.67 \\
{[0.47]}\end{array}$ & $\begin{array}{c}0.48 \\
{[0.50]}\end{array}$ \\
\hline Years of Education & $\begin{array}{l}11.9 \\
{[1.5]}\end{array}$ & $\begin{array}{l}12.4 \\
{[1.5]}\end{array}$ \\
\hline Years of Education Missing & $\begin{array}{c}0.10 \\
{[0.30]}\end{array}$ & $\begin{array}{c}0.05 \\
{[0.22]}\end{array}$ \\
\hline Tenure (years)* & $\begin{array}{c}11.6 \\
{[12.4]}\end{array}$ & $\begin{array}{c}5.7 \\
{[5.8]}\end{array}$ \\
\hline Tenure < 1 year $(\%) *$ & $\begin{array}{c}0.08 \\
{[0.27]}\end{array}$ & $\begin{array}{c}0.13 \\
{[0.34]}\end{array}$ \\
\hline Production Worker & $\begin{array}{c}0.37 \\
{[0.49]}\end{array}$ & $\begin{array}{c}0.40 \\
{[0.49]}\end{array}$ \\
\hline Works 1st Shift (\%) & $\begin{array}{c}0.77 \\
{[0.42]}\end{array}$ & $\begin{array}{c}0.89 \\
{[0.31]}\end{array}$ \\
\hline \# of Workers in Department & $\begin{array}{c}9.4 \\
{[6.6]}\end{array}$ & $\begin{array}{l}10.7 \\
{[7.4]}\end{array}$ \\
\hline Hourly Wage. Nov. $1992^{* *}$ & $\begin{array}{l}11.06 \\
{[3.24]}\end{array}$ & $\begin{array}{l}10.35 \\
{[2.45]}\end{array}$ \\
\hline $\begin{array}{l}\text { Avg. \% of Regular Hours Not Worked per Week. } \\
1992\end{array}$ & $\begin{array}{c}0.06 \\
{[0.05]}\end{array}$ & $\begin{array}{l}0.07 \\
{[0.04]}\end{array}$ \\
\hline Total Number of Performance Nominntions, 1992 & $\begin{array}{c}0.76 \\
{[0.90]}\end{array}$ & $\begin{array}{c}0.81 \\
{[0.91]}\end{array}$ \\
\hline Total Number of Performance Wins, 1992 & $\begin{array}{c}0.15 \\
{[0.36]}\end{array}$ & $\begin{array}{c}0.22 \\
{[0.55]}\end{array}$ \\
\hline Hourly Wage, Jan 1994** & $\begin{array}{l}11.52 \\
{[3.42]}\end{array}$ & $\begin{array}{l}10.87 \\
{[2.55]}\end{array}$ \\
\hline $\begin{array}{l}\text { Avg. \% of Regular Hours No Worked per Week. } \\
1993\end{array}$ & $\begin{array}{c}0.05 \\
{[0.03]}\end{array}$ & $\begin{array}{l}0.05 \\
{[0.03]}\end{array}$ \\
\hline Total Number of Performance Nominations, 1993 & $\begin{array}{c}0.80 \\
{[1.10]}\end{array}$ & $\begin{array}{l}1.10 \\
{[1.37]}\end{array}$ \\
\hline Total Number of Performance Wins, 1993 & $\begin{array}{c}0.33 \\
{[0.65]}\end{array}$ & $\begin{array}{c}0.42 \\
{[0.68]}\end{array}$ \\
\hline Total "Potential" Hours of Class Attended & & $\begin{array}{l}37.4 \\
{[28.5]}\end{array}$ \\
\hline Total "Actual" Hours of Class Attended & & $\begin{array}{l}28.5 \\
{[23.8]}\end{array}$ \\
\hline No. of Observations & 99 & 121 \\
\hline
\end{tabular}

* Tenure is as of November. $1992 . \quad$ All wages are in 1993 dollars. 
Table 3

Training Participation Probits

(Asymptotic Standard Errors)

Dependent Variable: 1 = Ever Participates

\begin{tabular}{|c|c|c|c|c|c|c|}
\hline & \multicolumn{4}{|c|}{ Manufacturing Co. } & \multirow{2}{*}{\multicolumn{2}{|c|}{$\begin{array}{c}\text { Service Co. } \\
\text { Took Any Class }\end{array}$}} \\
\hline & \multicolumn{2}{|c|}{ Took Any Class } & \multicolumn{2}{|c|}{ Took Oxcupationsl Class } & & \\
\hline & $\begin{array}{l}\text { Probit } \\
\text { Coeff. }\end{array}$ & $8 \mathrm{P} / 0 \mathrm{X}$ & $\begin{array}{l}\text { Probit } \\
\text { Coeff. }\end{array}$ & $8 P / 5 X$ & $\begin{array}{l}\text { Probit } \\
\text { Coeff. }\end{array}$ & $\delta \mathrm{P} / 0 \mathrm{X} *$ \\
\hline Age & $\begin{array}{c}0.167 \\
(0.056)\end{array}$ & 0.060 & $\begin{array}{c}0.117 \\
(0.067)\end{array}$ & 0.028 & $\begin{array}{c}0.056 \\
(0.058)\end{array}$ & 0.022 \\
\hline $\begin{array}{l}\text { Age } \\
(+10)\end{array}$ & $\begin{array}{l}-0.021 \\
(0.007)\end{array}$ & -0.007 & $\begin{array}{l}-0.016 \\
(0.008)\end{array}$ & -0.004 & $\begin{array}{l}-0.011 \\
(0.006)\end{array}$ & -0.004 \\
\hline Female & $\begin{array}{c}0.279 \\
(0.154)\end{array}$ & 0.101 & $\begin{array}{l}-0.151 \\
(0.181)\end{array}$ & -0.036 & $\begin{array}{c}0.314 \\
(0.242)\end{array}$ & 0.124 \\
\hline Non-white & $\begin{array}{c}0.011 \\
(0.126)\end{array}$ & 0.004 & $\begin{array}{c}0.152 \\
(0.146)\end{array}$ & 0.032 & $\begin{array}{l}-0.074 \\
(0.249)\end{array}$ & -0.029 \\
\hline Married & $\begin{array}{r}0.379 \\
(0.130)\end{array}$ & 0.137 & $\begin{array}{c}0.134 \\
(0.143)\end{array}$ & 0.036 & $\begin{array}{l}-0.463 \\
(0.222)\end{array}$ & -0.183 \\
\hline Years of Education & $\begin{array}{c}0.173 \\
(0.051)\end{array}$ & 0.063 & $\begin{array}{c}0.140 \\
(0.057)\end{array}$ & 0.033 & $\begin{array}{c}0.074 \\
(0.076)\end{array}$ & 0.029 \\
\hline Tenure (years) & $\begin{array}{c}0.035 \\
(0.035)\end{array}$ & 0.013 & $\begin{array}{c}0.026 \\
(0.041)\end{array}$ & 0.006 & $\begin{array}{l}-0.080 \\
(0.044)\end{array}$ & -0.032 \\
\hline $\begin{array}{l}\text { Tenure } \\
(+10)\end{array}$ & $\begin{array}{l}-0.018 \\
(0.013)\end{array}$ & -0.006 & $\begin{array}{l}-0.013 \\
(0.016)\end{array}$ & -0.003 & $\begin{array}{c}0.010 \\
(0.009)\end{array}$ & 0.004 \\
\hline Workd 1st Shift & $\begin{array}{l}-0.137 \\
(0.148)\end{array}$ & -0.049 & $\begin{array}{l}-0.091 \\
(0.160)\end{array}$ & -0.022 & $\begin{array}{c}1.367 \\
(0.303)\end{array}$ & 0.541 \\
\hline Production Worler & & & & & $\begin{array}{c}0.017 \\
(0.271)\end{array}$ & 0.007 \\
\hline Department Size & & & & & $\begin{array}{c}0.040 \\
(0.018)\end{array}$ & 0.016 \\
\hline $\begin{array}{l}\text { Log(Bourly Wage). } \\
\text { Oct. } 1992\end{array}$ & $\begin{array}{l}-5.621 \\
(1.260)\end{array}$ & -2.036 & $\begin{array}{l}-3.702 \\
(1.470)\end{array}$ & -0.886 & $\begin{array}{l}-0.920 \\
(0.573)\end{array}$ & -0.364 \\
\hline No. of Job Bids. 1992 & $\begin{array}{c}0.127 \\
(0.060)\end{array}$ & 0.046 & $\begin{array}{c}0.144 \\
(0.061)\end{array}$ & 0.034 & & \\
\hline $\begin{array}{l}\text { Ave \% of Regular Hours } \\
\text { Warked per Week. } 1992\end{array}$ & & & & & $\begin{array}{l}-6.225 \\
(3.256)\end{array}$ & -2.463 \\
\hline $\begin{array}{l}\text { No. of Vacation Days } \\
\text { Allowed, } 1992\end{array}$ & & & & & $\begin{array}{l}-0.013 \\
(0.033)\end{array}$ & -0.005 \\
\hline $\begin{array}{l}\text { Toual Number of Performance } \\
\text { Nominations. } 1992\end{array}$ & & & & & $\begin{array}{c}0.055 \\
(0.118)\end{array}$ & 0.022 \\
\hline Pseuda-R & 0.107 & & 0.076 & & 0.297 & \\
\hline No. of Observations & 503 & & 503 & & & 220 \\
\hline
\end{tabular}

Notes: All probits included a constant. The equation for the service company also included a dummy variable indicating whether education is missine and the equation for the menufacturing compeny inchuded a dummy varisble indicating whether the wark shift is missing.

- The derivatives of the probabilities are evaluated at the means of the independent variables. 
training. There is not a statistically significant effect of the shift on training in the manufacturing company, probably because training courses were offered during all day shifts at this company. Workers who bid for job openings in the previous year were more likely to undergo training. Lastly, we find a negative relationship between the wage rate and the probability of training.

In several important respects, selection into training is different at the service company. Age, gender, race, and education are statistically insignificant determinants of training. The probability of undergoing training tends to fall slightly during the first four years of job tenure, and then rise thereafter (p-value equals 0.13 ). Higher paid workers are less likely to attend training. Workers on the first shift are significantly more likely to attend training, probably because courses were only offered during the first shift. Workers who are part of larger departments are more likely to have attended training, perbaps because it was easier for someone else to cover for them while they were off the floor. These findings point to negative selection into training, with the least skilled workers more likely to select training.

\section{The Effects of Training}

\section{A. Wage Effects}

We estimate a variety of models to determine the impact on wages of participating in job training. Because we were particularly concerned about self-selection into training, the basic specification we estimate is:

(1) $\Delta \ln W_{1 t}=\alpha+X_{1 t} \beta+\gamma T_{1 t}+\varepsilon_{1 t}$ 
where $\Delta \ln W_{1 t}$ is the change in the log hourly wage between 1992 and $1994, X_{t t}$ is a row vector of covariates (including age, tenure, gender, etc.), and $T_{\mathrm{tt}}$ is a dummy variable that equals 1 if the worker participated in the training program between 1992 and 1994, and 0 if not. The coefficient $\gamma$ measures the proportionate growth in wages associated with training. By modelling wage growth, we hope to net out any omitted fixed worker effects. Because wage growth is sensitive to tenure, we include a flexible functional form of tenure." We assume $\varepsilon_{\mathrm{at}}$ is an error term that is uncorrelated with $T_{16}$. In some specifications, we also include as an explanatory variable the log wage in 1991, to allow for differential wage growth across the wage distribution.

Results of OLS growth equations are reported in Table $4 a$ for the manufacturing company and $4 \mathrm{~b}$ for the service company. (Standard cross-sectional semi-log wage regressions for the samples are reported in the Appendix Table 1.) Because of the smaller sample size and higher residual variance, the estimated training effects are much less precise for the service company than for the manufacturing company. When no other covariates are included, the wage growth equations indicate a positive association between training and wage growth in both companies. Including age and tenure greatly attenuates the training effect for the service company. If we include a quadratic in age and tenure, demographic variables, and job characteristic variables (column (3)), wage growth is insignificantly related to the variable that measures whether the worker took any training at either company.

When we include the $1991 \log$ wage as an explanatory variable in column (4), the coefficient on the training variable is even smaller for the manufacturing company and negative with a t-ratio close to 2 for the service company. One problem with this

4 Our results were qualitatively similar if we included a quartic in tenure, and dummy variables indicating different ranges of tenure. 
Table 4a

The Effect of Training on Wages

Manufacturing Company

Dependent Variable: Log(Wage in 1994Wage 1982) (Standard Errors)

\begin{tabular}{|c|c|c|c|c|c|c|c|c|}
\hline & \multicolumn{4}{|c|}{ Participant = Any Classes } & \multicolumn{4}{|c|}{ Participant = Oxupational Classes } \\
\hline & (1) & (2) & (3) & (4) & (5) & (6) & (7) & (8) \\
\hline Participant & $\begin{array}{c}0.004 \\
(0.002)\end{array}$ & $\begin{array}{c}0.004 \\
(0.002)\end{array}$ & $\begin{array}{c}0.003 \\
(0.002)\end{array}$ & $\begin{array}{c}0.002 \\
(0.002)\end{array}$ & $\begin{array}{c}0.006 \\
(0.002)\end{array}$ & $\begin{array}{c}0.005 \\
(0.002)\end{array}$ & $\begin{array}{c}0.005 \\
(0.002)\end{array}$ & $\begin{array}{c}0.004 \\
(0.002)\end{array}$ \\
\hline $\begin{array}{l}\text { Age } \\
(+10)\end{array}$ & & $\begin{array}{l}-0.002 \\
(0.001)\end{array}$ & $\begin{array}{c}0.013 \\
(0.007)\end{array}$ & $\begin{array}{c}0.016 \\
(0.007)\end{array}$ & & $\begin{array}{l}-0.002 \\
(0.001)\end{array}$ & $\begin{array}{c}0.014 \\
(0.007)\end{array}$ & $\begin{array}{c}0.016 \\
(0.007)\end{array}$ \\
\hline $\begin{array}{l}\mathrm{Age}^{2} \\
(+1000)\end{array}$ & & & $\begin{array}{l}-0.019 \\
(0.009)\end{array}$ & $\begin{array}{l}-0.022 \\
(0.009)\end{array}$ & & & $\begin{array}{l}-0.018 \\
(0.008)\end{array}$ & $\begin{array}{l}-0.022 \\
(0.009)\end{array}$ \\
\hline $\begin{array}{l}\text { Tenure (Yrs) } \\
(+10)\end{array}$ & & $\begin{array}{l}-0.001 \\
(0.001)\end{array}$ & $\begin{array}{l}-0.010 \\
(0.005)\end{array}$ & $\begin{array}{l}-0.007 \\
(0.006)\end{array}$ & & $\begin{array}{l}-0.001 \\
(0.001)\end{array}$ & $\begin{array}{l}-0.010 \\
(0.005)\end{array}$ & $\begin{array}{l}-0.007 \\
(0.005)\end{array}$ \\
\hline $\begin{array}{l}\text { Tenure } \\
(+1000)\end{array}$ & & & $\begin{array}{c}0.028 \\
(0.017)\end{array}$ & $\begin{array}{c}0.023 \\
(0.017)\end{array}$ & & & $\begin{array}{c}0.028 \\
(0.017)\end{array}$ & $\begin{array}{l}-0.023 \\
(0.017)\end{array}$ \\
\hline Female & & & $\begin{array}{c}0.005 \\
(0.002)\end{array}$ & $\begin{array}{c}0.003 \\
(0.002)\end{array}$ & & & $\begin{array}{c}0.005 \\
(0.002)\end{array}$ & $\begin{array}{c}0.003 \\
(0.002)\end{array}$ \\
\hline Nonwhite & & & $\begin{array}{c}0.002 \\
(0.002)\end{array}$ & $\begin{array}{c}0.000 \\
(0.002)\end{array}$ & & & $\begin{array}{c}0.002 \\
(0.002)\end{array}$ & $\begin{array}{l}-0.0001 \\
(0.002)\end{array}$ \\
\hline Ever-married & & & $\begin{array}{l}-0.003 \\
(0.002)\end{array}$ & $\begin{array}{l}-0.002 \\
(0.002)\end{array}$ & & & $\begin{array}{l}-0.002 \\
(0.002)\end{array}$ & $\begin{array}{l}-0.001 \\
(0.002)\end{array}$ \\
\hline Education (Yrs) & & & $\begin{array}{l}-0.001 \\
(0.001)\end{array}$ & $\begin{array}{l}-0.0002 \\
(0.0007)\end{array}$ & & & $\begin{array}{l}-0.001 \\
(0.001)\end{array}$ & $\begin{array}{l}-0.0003 \\
(0.0007)\end{array}$ \\
\hline 1st Shift & & & $\begin{array}{c}0.004 \\
(0.002)\end{array}$ & $\begin{array}{c}0.003 \\
(0.002)\end{array}$ & & & $\begin{array}{c}0.004 \\
(0.002)\end{array}$ & $\begin{array}{c}0.003 \\
(0.002)\end{array}$ \\
\hline $\begin{array}{l}\text { No. of Job Bids } \\
(1992)(+10)\end{array}$ & & & $\begin{array}{l}-0.015 \\
(0.010)\end{array}$ & $\begin{array}{l}-0.016 \\
(0.010)\end{array}$ & & & $\begin{array}{l}-0.015 \\
(0.010)\end{array}$ & $\begin{array}{l}-0.016 \\
(0.010)\end{array}$ \\
\hline $\begin{array}{l}\text { No. Job Upgrades } \\
(1992)(+10)\end{array}$ & & & $\begin{array}{c}0.018 \\
(0.036)\end{array}$ & $\begin{array}{c}0.010 \\
(0.036)\end{array}$ & & & $\begin{array}{c}0.014 \\
(0.036)\end{array}$ & $\begin{array}{c}0.007 \\
(0.036)\end{array}$ \\
\hline Log Wage in 1991 & & & & $\begin{array}{l}-0.061 \\
(0.015)\end{array}$ & & & & $\begin{array}{l}-0.060 \\
(0.015)\end{array}$ \\
\hline Constant & $\begin{array}{c}0.017 \\
(0.001)\end{array}$ & $\begin{array}{c}0.027 \\
(0.004)\end{array}$ & $\begin{array}{c}0.009 \\
(0.016)\end{array}$ & $\begin{array}{c}0.151 \\
(0.038)\end{array}$ & $\begin{array}{c}0.018 \\
(0.001)\end{array}$ & $\begin{array}{c}0.027 \\
(0.004)\end{array}$ & $\begin{array}{c}0.008 \\
(0.016)\end{array}$ & $\begin{array}{c}0.150 \\
(0.038)\end{array}$ \\
\hline $\mathrm{R}^{2}$ & 0.011 & 0.026 & 0.070 & 0.101 & 0.012 & 0.026 & 0.073 & 0.105 \\
\hline
\end{tabular}

Notes: Sample size is 503 except in columns (4) and (8) where it is 496 . Regressions also include a dummy variable indicating whether the shift is missing. 
Table $4 b$

The Effect of Training on Wages

Service Company

Dependent Variable: Log(Wage in 1994/Wage in 1992)

\begin{tabular}{|c|c|c|c|c|}
\hline & (1) & (2) & (3) & (4) \\
\hline Participant & $\begin{array}{c}0.010 \\
(0.007)\end{array}$ & $\begin{array}{c}0.0001 \\
(0.0074)\end{array}$ & $\begin{array}{l}-0.005 \\
(0.008)\end{array}$ & $\begin{array}{l}-0.016 \\
(0.008)\end{array}$ \\
\hline $\begin{array}{l}\text { Age } \\
(+10)\end{array}$ & & $\begin{array}{l}-0.009 \\
(0.003)\end{array}$ & $\begin{array}{l}-0.009 \\
(0.017)\end{array}$ & $\begin{array}{l}-0.016 \\
(0.017)\end{array}$ \\
\hline $\begin{array}{l}\text { Age }^{2} \\
(+1000)\end{array}$ & & & $\begin{array}{l}-0.002 \\
(0.018)\end{array}$ & $\begin{array}{l}-0.002 \\
(0.018)\end{array}$ \\
\hline $\begin{array}{l}\text { Tenure (Yrs) } \\
(+10)\end{array}$ & & $\begin{array}{r}0.0001 \\
(0.004)\end{array}$ & $\begin{array}{l}-0.018 \\
(0.009)\end{array}$ & $\begin{array}{l}-0.006 \\
(0.010)\end{array}$ \\
\hline $\begin{array}{l}\text { Tenure } \\
(+1000)\end{array}$ & & & $\begin{array}{c}0.037 \\
(0.019)\end{array}$ & $\begin{array}{c}0.020 \\
(0.019)\end{array}$ \\
\hline Female & & & $\begin{array}{c}0.007 \\
(0.007)\end{array}$ & $\begin{array}{c}0.007 \\
(0.008)\end{array}$ \\
\hline Nonwhite & & & $\begin{array}{l}-0.009 \\
(0.008)\end{array}$ & $\begin{array}{l}-0.007 \\
(0.008)\end{array}$ \\
\hline Ever-married & & & $\begin{array}{l}-0.0001 \\
(0.007)\end{array}$ & $\begin{array}{l}-0.004 \\
(0.007)\end{array}$ \\
\hline Education ( $Y_{r s}$ ) & & & $\begin{array}{l}-0.0002 \\
(0.002)\end{array}$ & $\begin{array}{c}0.002 \\
(0.003)\end{array}$ \\
\hline Production Worker & & & $\begin{array}{c}0.026 \\
(0.009)\end{array}$ & $\begin{array}{c}0.014 \\
(0.009)\end{array}$ \\
\hline 1st Shift & & & $\begin{array}{c}0.016 \\
(0.010)\end{array}$ & $\begin{array}{c}0.026 \\
(0.010)\end{array}$ \\
\hline $\begin{array}{l}\text { Size of Department } \\
(+10)\end{array}$ & & & $\begin{array}{l}-0.014 \\
(0.006)\end{array}$ & $\begin{array}{l}-0.001 \\
(0.001)\end{array}$ \\
\hline Log Wage in 1991 & & & & $\begin{array}{l}-0.036 \\
(0.018)\end{array}$ \\
\hline Constant & $\begin{array}{c}0.039 \\
(0.005)\end{array}$ & $\begin{array}{c}0.085 \\
(0.014)\end{array}$ & $\begin{array}{c}0.094 \\
(0.047)\end{array}$ & $\begin{array}{c}0.163 \\
(0.060)\end{array}$ \\
\hline $\mathrm{R}^{2}$ & 0.010 & 0.065 & 0.151 & 0.195 \\
\hline No. of Observations & 220 & 220 & 220 & 197 \\
\hline
\end{tabular}

Notes: Standard errors are in parentheses. Regressions also a dummy variable indicating whether education is missing. 
specification, however, is that we must drop 10 percent of our sample at the service company because workers must be employed for three continuous years to have wages each period; thus, low tenure workers are dropped from the sample. If we restrict the sample to lowtenure workers (tenure under 5 years) and estimate the specification in column (3) for the service company, the training coefficient is 0.015 with a standard error of 0.014 . Eliminating low-tenure workers changes the composition of the sample, and may have an important effect on the estimated return to training.

If we focus solely on occupational classes (columns 5-8 of Table $4 \mathrm{a}$ ), the training variable has a more robust, positive association with wage growth at the manufacturing company. For example, taking an occupational education class is estimated to increase earnings growth by 0.6 percent when no covariates are included, and by 0.4 percent when age, tenure, demographic variables, and the pre-training wage are held constant (column 8). The findings for the occupational education classes are consistent with the importance that company officials attached to specific occupational skills, such as the ability to read a blueprint. In some jobs in this company, proficiency in reading blueprints is a requirement for promotion.

\section{B. Effects on Job Bids and Uprrades}

At the manufacturing company, 23\% of the employees in our sample bid for jobs in 1993. Just under $30 \%$ percent of those who applied received at least one upgrade. ${ }^{5}$ In Tables $5 a$ and $5 b$ we analyze the extent to which the training classes may have affected the likelihood that an employee bid for a job or received a job upgrade in 1993 using an ordered

\footnotetext{
${ }^{5}$ These percentages are roughly the same for the full sample before our exclusions.
} 
probit model. This model assumes a latent-variable structure of the form:

$$
\mathbf{y}^{*}=\mathbf{X} \boldsymbol{\beta}+\varepsilon .
$$

We observe (assuming three categories),

$$
\begin{aligned}
& y=0^{\circ} \text { if } \varepsilon<X \beta, \\
& y=1 \text { if } X \beta<\varepsilon<X \beta+\lambda, \\
& y=2 \text { if X } \beta+\lambda<\varepsilon,
\end{aligned}
$$

where $\lambda>0$, and,

$$
\begin{aligned}
& P_{0}=F(X \beta) \\
& P_{1}=F(X \beta+\lambda)-F(X \beta) \\
& P_{2}=1-F(X \beta+\lambda) .
\end{aligned}
$$

The model easily generalizes to more than three categories.

Because union rules stipulate that the employer must choose the most senior employee among those qualified when filling a job posting, we were careful to control for tenure (or seniority). In the results shown here, we include a quartic in tenure, however, the results are robust to several alternative specifications. As usual, we define participation in two ways: having taken any of the training classes and having taken any of the occupational classes.

In the columns (1) and (5) of Table $5 a$ we find that training participants bid for more jobs than non-participants whether they took any class or took any occupational class. The difference is statistically significant at the $5 \%$ level. Because the coefficients from the ordered probit are not easily interpreted, another way to gauge the difference is that those who took any class had a 10 percentage point increase in their likelihood of bidding for at

\footnotetext{
'We have also modeled the data using OLS, a binary probit as to whether an individual ever bid or ever received an upgrade, and a Poisson model for count date. The results are invariant to the choice among these models.
} 


\section{Table 5a}

\section{The Effect of Training on Number of Job Bids Manufacturing Company Ordered Probit Model}

\begin{tabular}{|c|c|c|c|c|c|c|}
\hline & \multicolumn{3}{|c|}{ Participant = Any Classes } & \multicolumn{3}{|c|}{ Participant = Occupational Classes } \\
\hline & $(1)$ & $(2)$ & (3) & $(5)$ & $(6)$ & (7) \\
\hline Participant & $\begin{array}{c}0.390 \\
(0.121)\end{array}$ & $\begin{array}{c}0.416 \\
(0.138)\end{array}$ & $\begin{array}{c}0.403 \\
(0.139)\end{array}$ & $\begin{array}{c}0.752 \\
(0.140)\end{array}$ & $\begin{array}{c}0.745 \\
(0.154)\end{array}$ & $\begin{array}{c}0.750 \\
(0.156)\end{array}$ \\
\hline No. Job Bids, 1992 & & $\begin{array}{c}0.407 \\
(0.059)\end{array}$ & $\begin{array}{c}0.410 \\
(0.060)\end{array}$ & & $\begin{array}{c}0.417 \\
(0.060)\end{array}$ & $\begin{array}{c}0.419 \\
(0.060)\end{array}$ \\
\hline No. Job Upgrades, 1992 & & $\begin{array}{l}-0.339 \\
(0.217)\end{array}$ & $\begin{array}{c}-0.444 \\
(0.227)\end{array}$ & & $\begin{array}{l}-0.450 \\
(0.221)\end{array}$ & $\begin{array}{l}-0.534 \\
(0.231)\end{array}$ \\
\hline$\lambda_{4}$ & $\begin{array}{c}0.879 \\
(0.079)\end{array}$ & $\begin{array}{l}-0.203 \\
(2.887)\end{array}$ & $\begin{array}{c}-1.193 \\
(2.993)\end{array}$ & $\begin{array}{c}0.889 \\
(0.070)\end{array}$ & $\begin{array}{l}-0.170 \\
(2.887)\end{array}$ & $\begin{array}{l}-0.879 \\
(2.991)\end{array}$ \\
\hline$\lambda_{2}$ & $\begin{array}{c}1.456 \\
(0.093)\end{array}$ & $\begin{array}{c}0.528 \\
(2.887)\end{array}$ & $\begin{array}{l}-0.446 \\
(2.992)\end{array}$ & $\begin{array}{c}1.484 \\
(0.087)\end{array}$ & $\begin{array}{c}0.580 \\
(2.887)\end{array}$ & $\begin{array}{l}-0.109 \\
(2.990)\end{array}$ \\
\hline$\lambda_{3}$ & $\begin{array}{c}1.725 \\
(0.105)\end{array}$ & $\begin{array}{c}0.883 \\
(2.886)\end{array}$ & $\begin{array}{l}-0.101 \\
(2.992)\end{array}$ & $\begin{array}{c}1.764 \\
(0.101)\end{array}$ & $\begin{array}{c}0.947 \\
(2.887)\end{array}$ & $\begin{array}{c}0.248 \\
(2.989)\end{array}$ \\
\hline$\lambda_{4}$ & $\begin{array}{c}2.034 \\
(0.125)\end{array}$ & $\begin{array}{c}1.284 \\
(2.887)\end{array}$ & $\begin{array}{c}0.313 \\
(2.992)\end{array}$ & $\begin{array}{c}2.089 \\
(0.124)\end{array}$ & $\begin{array}{c}1.369 \\
(2.888)\end{array}$ & $\begin{array}{c}0.682 \\
(2.990)\end{array}$ \\
\hline$\lambda_{8}$ & $\begin{array}{c}2.244 \\
(0.145)\end{array}$ & $\begin{array}{c}1.546 \\
(2.889)\end{array}$ & $\begin{array}{c}0.582 \\
(2.992)\end{array}$ & $\begin{array}{c}2.312 \\
(0.146)\end{array}$ & $\begin{array}{c}1.647 \\
(2.889)\end{array}$ & $\begin{array}{c}0.967 \\
(2.990)\end{array}$ \\
\hline$\lambda_{0}$ & $\begin{array}{c}2.526 \\
(0.182)\end{array}$ & $\begin{array}{c}1.874 \\
(2.890)\end{array}$ & $\begin{array}{c}0.919 \\
(2.993)\end{array}$ & $\begin{array}{c}2.609 \\
(0.185)\end{array}$ & $\begin{array}{c}1.994 \\
(2.891)\end{array}$ & $\begin{array}{c}1.322 \\
(2.992)\end{array}$ \\
\hline$\lambda_{1}$ & $\begin{array}{c}2.609 \\
(0.195)\end{array}$ & $\begin{array}{c}1.972 \\
(2.891)\end{array}$ & $\begin{array}{c}1.019 \\
(2.994)\end{array}$ & $\begin{array}{c}2.696 \\
(0.200)\end{array}$ & $\begin{array}{c}2.097 \\
(2.892)\end{array}$ & $\begin{array}{c}1.426 \\
(2.992)\end{array}$ \\
\hline$\lambda_{\mathbf{B}}$ & $\begin{array}{c}2.713 \\
(0.216)\end{array}$ & $\begin{array}{c}2.100 \\
(2.893)\end{array}$ & $\begin{array}{c}1.151 \\
(2.995)\end{array}$ & $\begin{array}{c}2.805 \\
(0.221)\end{array}$ & $\begin{array}{c}2.231 \\
(2.894)\end{array}$ & $\begin{array}{c}1.564 \\
(2.994)\end{array}$ \\
\hline$\lambda_{\mathbf{B}}$ & $\begin{array}{c}3.075 \\
(0.320)\end{array}$ & $\begin{array}{c}2.523 \\
(2.902)\end{array}$ & $\begin{array}{c}1.592 \\
(3.004)\end{array}$ & $\begin{array}{c}3.174 \\
(0.324)\end{array}$ & $\begin{array}{c}2.659 \\
(2.904)\end{array}$ & $\begin{array}{c}2.007 \\
(3.003)\end{array}$ \\
\hline $\begin{array}{l}\text { Controls for Personal } \\
\text { Characterics? }\end{array}$ & no & yex & yes & no & yes & yes \\
\hline $\begin{array}{l}\text { Controls for Wage in } \\
1991 ?\end{array}$ & no & no & yes & no & no & yes \\
\hline Pseuda-R $R^{2}$ & 0.012 & 0.148 & 0.153 & 0.033 & 0.164 & 0.170 \\
\hline $\mathbf{N}$ & 503 & 503 & 496 & 503 & 503 & 496 \\
\hline
\end{tabular}

Notes: Personal characteristes include a quadratic in age, a quartic in tenure, log wage in 1992. dummy variables indicating whether female, nonwhite, ever-married, works 1 st shift or whether shift is missing, and years of education. 
least one job than non-participants; those who took at least one occupational class were 21 points more likely to bid than non-participants and those who never took an occupational class. ${ }^{7}$ In columns (2) and (6) we add controls for the number of job bids and job upgrades in 1992. The coefficient on the number of previous job upgrades is negative and insignificant. but the coefficients on the number of previous job bids is positive and statistically significant. Adding previous bids and job changes, as well as personal characteristics such as demographic variables, tenure, age, education, and log wage in 1992, increases the participation coefficients slightly. Finally, we also include the log wage that individuals employed at the company in 1991 earned as of July 1991. Although not shown, the coefficient is typically negative and insignificant. Further, it has little effect on the participation coefficients.

The results of the effect of the training classes on the number of job upgrades are presented in Table $5 \mathrm{~b}$ which has an identical structure to Table 5a. Again, the coefficients in columns (1) and (5) indicate that training participants were significantly more likely to receive job changes. Those who took at least one class are 7 points more likely than nonparticipants and those who took at least one occupational course are 8.5 points more likely than those who never took an occupational class to receive a job change. As in Table 5a, those taking classes continue to be more likely to receive job upgrades than non-participants conditional on personal characteristics and on the wage received in 1991 . Overall, the evidence suggests that the training program encourages employees to bid for more jobs and improves their likelihood of receiving job changes, assuming there are no additional selfselection effects for which we have not controlled.

7 The probability difference is based upon a binary probit and the derivative of the probability is evaluated at the mean of the independent variable. 
Table 5b

The Effect of Training on Number of Job Upgrades

Manufacturing Company

Ordered Probit Model

Dependent Variable: Number of Job Upgrades, 1993 (Asymptotic Standard Errors)

\begin{tabular}{|c|c|c|c|c|c|c|}
\hline & \multicolumn{3}{|c|}{ Participant $=$ Any Classes } & \multicolumn{3}{|c|}{ Participant $=$ Oocupational Classes } \\
\hline & $(1)$ & (2) & (3) & $(5)$ & $(6)$ & $(7)$ \\
\hline Participant & $\begin{array}{c}0.587 \\
(0.180)\end{array}$ & $\begin{array}{c}0.739 \\
(0.215)\end{array}$ & $\begin{array}{c}0.752 \\
(0.217)\end{array}$ & $\begin{array}{c}0.761 \\
(0.191)\end{array}$ & $\begin{array}{c}0.881 \\
(0.226)\end{array}$ & $\begin{array}{c}0.880 \\
(0.230)\end{array}$ \\
\hline No. Job Bids, 1992 & & $\begin{array}{c}0.071 \\
(0.093)\end{array}$ & $\begin{array}{c}0.067 \\
(0.093)\end{array}$ & & $\begin{array}{c}0.087 \\
(0.092)\end{array}$ & $\begin{array}{c}0.081 \\
(0.092)\end{array}$ \\
\hline No. Job Upgrades, 1992 & & $\begin{array}{l}-0.132 \\
(0.321)\end{array}$ & $\begin{array}{c}-0.143 \\
(0.329)\end{array}$ & & $\begin{array}{c}-0.283 \\
(0.330)\end{array}$ & $\begin{array}{l}-0.268 \\
(0.337)\end{array}$ \\
\hline$\lambda_{1}$ & $\begin{array}{l}1.805 \\
(0.132)\end{array}$ & $\begin{array}{l}-1.901 \\
(5.205)\end{array}$ & $\begin{array}{l}-2.924 \\
(5.493)\end{array}$ & $\begin{array}{c}1.754 \\
(0.112)\end{array}$ & $\begin{array}{l}-2.036 \\
(5.190)\end{array}$ & $\begin{array}{l}-2.502 \\
(5.377)\end{array}$ \\
\hline$\lambda_{2}$ & $\begin{array}{c}2.799 \\
(0.227)\end{array}$ & $\begin{array}{l}-0.727 \\
(5.204)\end{array}$ & $\begin{array}{l}-1.735 \\
(5.490)\end{array}$ & $\begin{array}{c}2.775 \\
(0.222)\end{array}$ & $\begin{array}{l}-0.833 \\
(5.189)\end{array}$ & $\begin{array}{l}-1.290 \\
(5.373)\end{array}$ \\
\hline $\begin{array}{l}\text { Controls for Personal } \\
\text { Characterics? }\end{array}$ & no & yes & yes & no & yes & yes \\
\hline $\begin{array}{l}\text { Controls for Wage in } \\
1991 \text { ? }\end{array}$ & no & no & yes & no & no & yes \\
\hline Pseudo- $R^{2}$ & 0.040 & 0.196 & 0.202 & 0.060 & 0.207 & 0.210 \\
\hline No. of Observations & 503 & 503 & 496 & 503 & 503 & 496 \\
\hline
\end{tabular}

Notes: Personal characteristcs include a quadratic in age, a quartic in tenure, log wage in 1992, dummy variables indicating whether female, nonwhite, ever-married, works 1 st shift or whether shift is missing. and years of education. 


\section{Effects on Performance Awards}

The results of the effect of the training program on performance awards in the service company are presented in Table 6. The estimates are from OLS regressions. Because a maximum of five individual nominations, four group nominations, and two awards of each type were received, we also estimated the models using ordered probits, as well as binary probits (on whether ever nominated or ever awarded) with similar results. The first column in each block presents the raw difference in the number of nominations or wins between participants and non-participants, the second column controls for past awards or nominations, and the final column also includes personal characteristics.

In looking at individual nominations, before conditioning on other variables, participants received 0.24 more nominations than did non-participants with a p-value equal to 0.076 . Forty-nine percent of participants were nominated for at least one individual award in 1993 , as compared to $36 \%$ of non-participants. In column (2), the coefficient on number of individual nominations received in 1992 is positive and significant at the $10 \%$ level suggesting that those who have received nominations in the past are more likely to receive them in the future. However, the coefficient on the number of individual nominations received in 1993 remains virtually unchanged, reflecting that the number of nominations received in 1992 is only weakly correlated with participant status (as also found in Table 3). With the addition of personal characteristics such as demographic information, years of education, and tenure, the coefficient decreases in size and becomes statistically insignificant at any typical significance level.

The effects of the classes on the number of individual awards, group nominations, and group awards were smaller in magnitude and statistically insignificant. In three of the four cases, controlling for past nominations or awards alone did not change the coefficient on the 


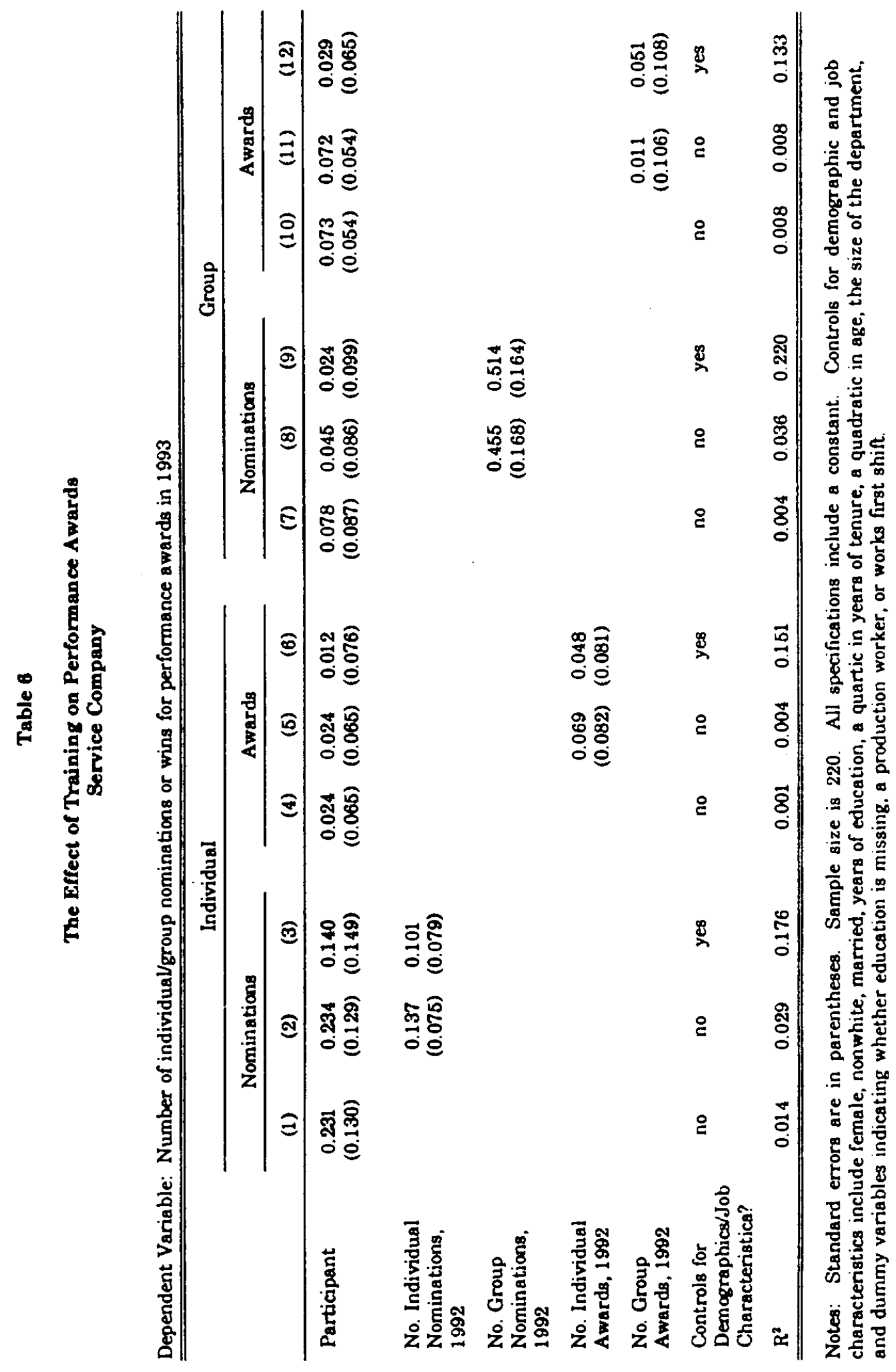


participation dummy, while adding personal characteristics had a relatively larger effect. Thus, while there is some evidence that training participants were more likely to be nominated for performance awards, the difference appears to be largely explained by other personal chairacteristics.

\section{Effects on Absenteeism}

To estimate the impact of participating in job training on worker absenteeism, we created a panel of weekly data on each employee's number (or fraction) of unpaid hours of work and the number of class hours the employee was scheduled to attend that week. We estimate the following basic specification using both random and fixed-effects models:

$$
h_{\mathrm{ts}}=\alpha+\mathrm{C}_{\mathrm{ts}} \beta+\mathrm{X}_{1} \gamma+\varepsilon_{\mathrm{s}}+\mathrm{u}_{\mathrm{ts}}
$$

where $h_{t t}$ is the number (or fraction) of non-paid hours each week, and $C_{i t}$ is the number of class hours for worker $i$ in week $t ; X_{1}$ is a vector of time-invariant individual characteristics. In the random effects model, $\varepsilon_{1}$ is modeled as an individual-specific component of the error term with variance $\sigma_{e}^{2}$, and $u_{1 t}$ a serially uncorrelated transitory component with variance $\sigma_{\mathrm{v}}^{2}$. The model is estimated by OLS on the quasi-differenced variables and some specifications also include individual covariates such as age, tenure, and education, as well as time effects. We also estimate a fixed effects model in which $\varepsilon_{\text {q }}$ is treated as an individual fixed effect, and again we include time effects in some specifications. In all cases, we exclude the week including Christmas from our sample since absenteeism was high and there were no classes that week.

Results of the absenteeism equations are presented in Tables $7 \mathrm{a}$ and $7 \mathrm{~b}$. In both 


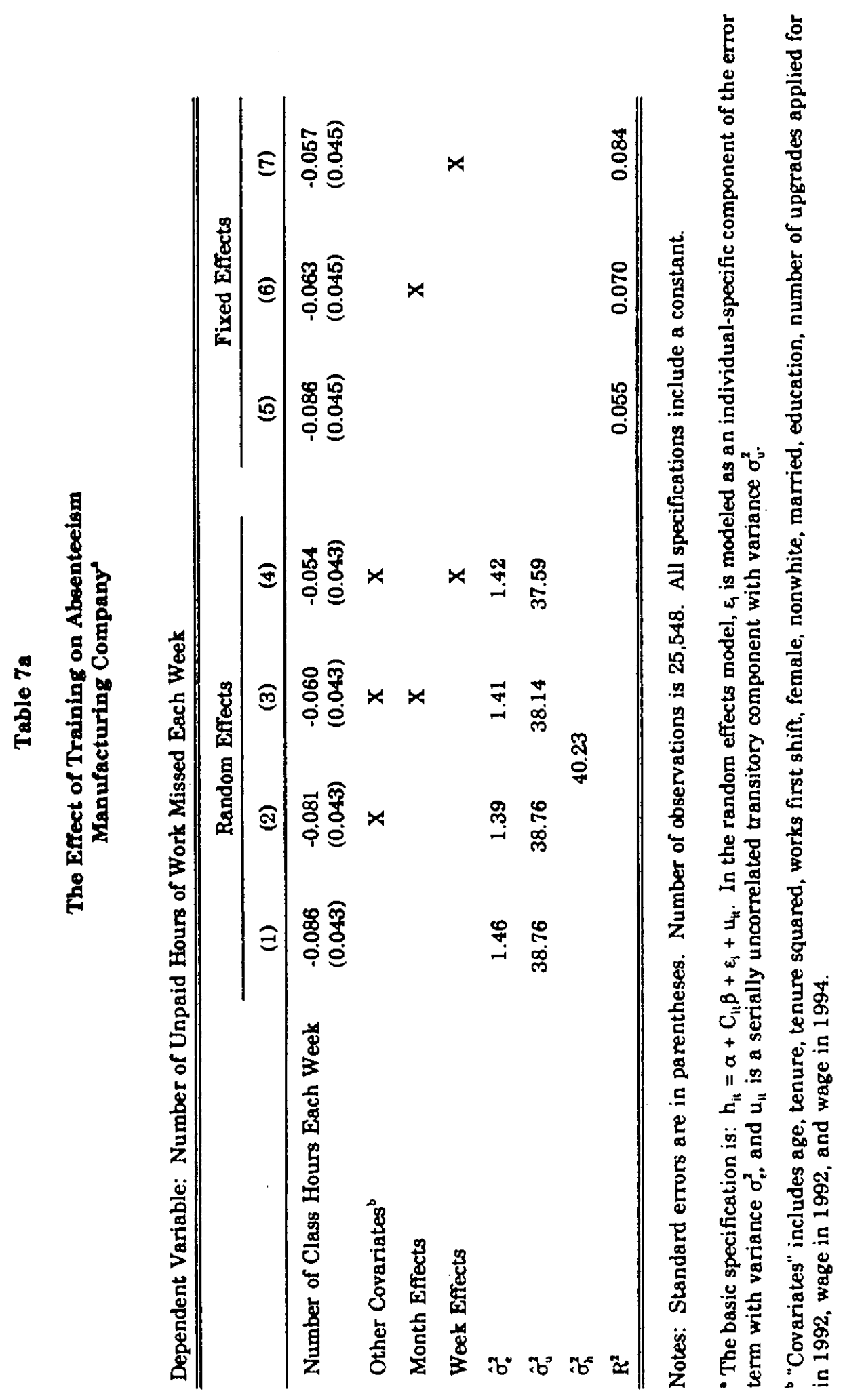




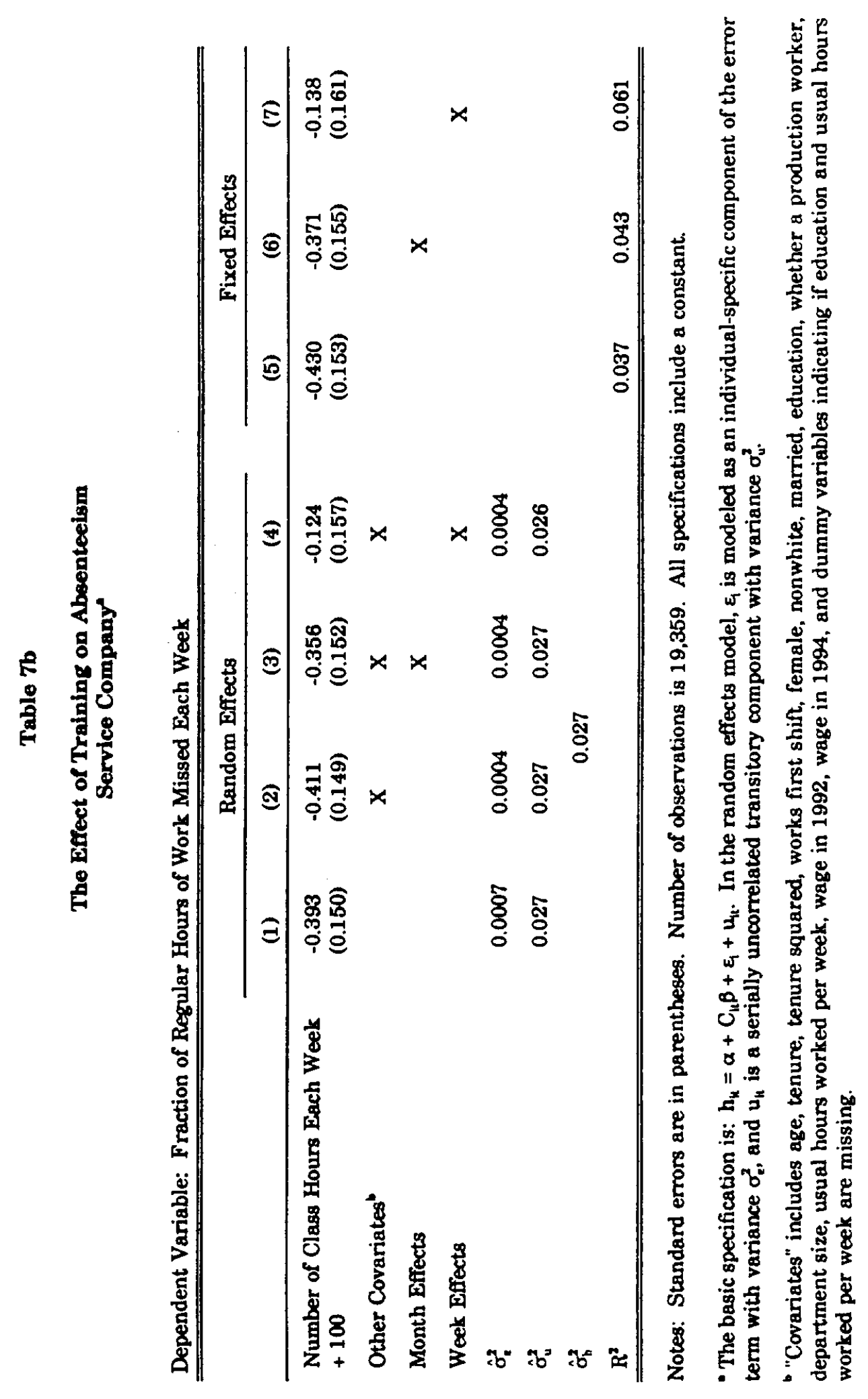


companies, there is a negative impact of classes on absenteeism and the results are similar using both random and fixed effects estimators. In the manufacturing company, before time effects are included, the number of class hours each week has a statistically significant negative effect on the number of unpaid hours missed that week. That is, those who were supposed to attend class appear more inclined to be at work that week. The effect is small, however. Each hour of class time reduces unpaid absenteeism by 0.08 hours. Given that workers in this company are paid $\$ 12.00$ per hour, on average, this effect translates into 96 cents of "recovered value" from production time for each hour of class each week, or about $\$ 8000$ for all workers over the duration of the program. Once time effects are added, the magnitude of the effect decreases by over 25 percent, and the coefficient is no longer statistically significant at conventional significance levels. Results in the service company are roughly similar. An additional class hour per week decreases the fraction of regular hours of work missed per week by 0.4 percent. Given an average work week of 37.5 hours this translates into 0.15 hours. The fact that the estimated coefficients fall in magnitude when week effects are added indicates that the courses were less likely to be scheduled during holidays or other times when absenteeism was high.

On the whole, this evidence suggests that the training program had some effect on absenteeism, although it is not conclusive. Even if our estimated coefficients are correct, the effect is small. At most, the reduction in absenteeism accounts for less than $10 \%$ of the cost of the program per worker. On the other hand, we have not considered the possible longerrun effect of the training program on absenteeism and tardiness, an effect that can only be determined in a longer follow-up. 


\section{E. Subjective Evaluations}

Our survey enables us to investigate the effect of participating in job training on the answers to a variety of subjective questions. For examples, we asked workers about their satisfaction'with their company, desire to take additional training classes, educational aspirations for their children and grandchildren, and job performance. We tabulated the mean responses to these questions for training participants and non-participants. In addition, we adjusted the differences between the participants and non-participants by estimating a regression of the response to subjective questions on an intercept, years of education, tenure, and gender and marital status dummies. These results are presented in Table $8 \mathrm{a}$ for the manufacturing company and Table $8 \mathrm{~b}$ for the service company.

For almost all of the subjective variables that we examined, there is not a statistically significant difference between the trainees and non-trainees. For example, 84 percent of training participants and 80 percent of non-participants reported that they like working at their company a lot or somewhat, with a t-ratio of 1.0 on the difference. (The corresponding figures are 92 and 90 percent at the service company.) Although trainees are less likely to apply for jobs in other companies, more likely to belong to religious and community organizations, have higher educational aspirations for their children or grandchildren, and are more likely to read books or magazines than non-trainees, the differences between trainees and non-trainees on these variables are all statistically insignificant and fairly small.

We find, however, that at both companies trainees are significantly more likely than non-trainees to report that they plan to take additional classes in the near future. This finding would be unexpected if trainees considered their training worthless. Perhaps more significantly, at the service company the average improvement in self-reported job performance is higher among trainees than among non-trainees. For example, trainees are 


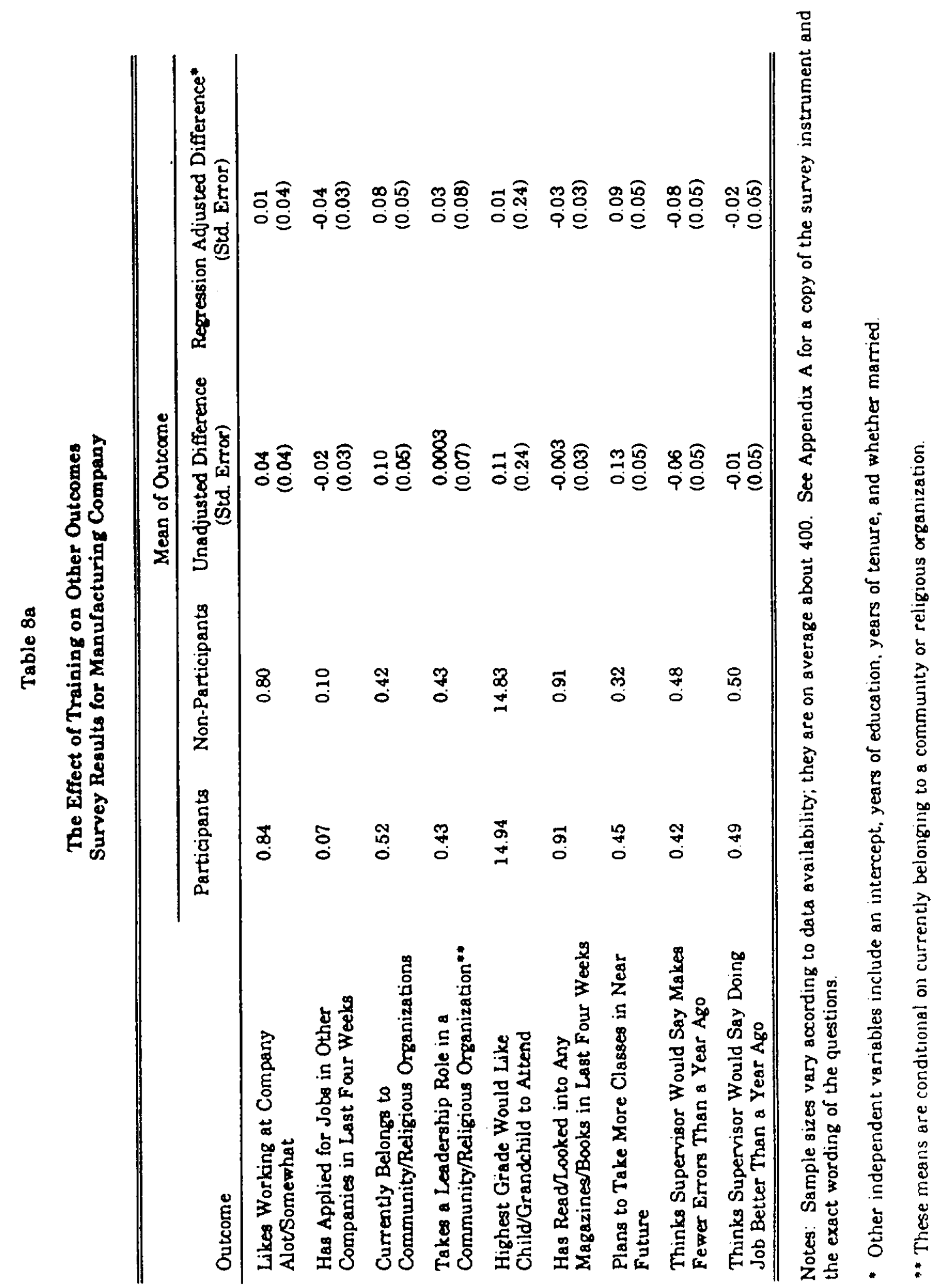




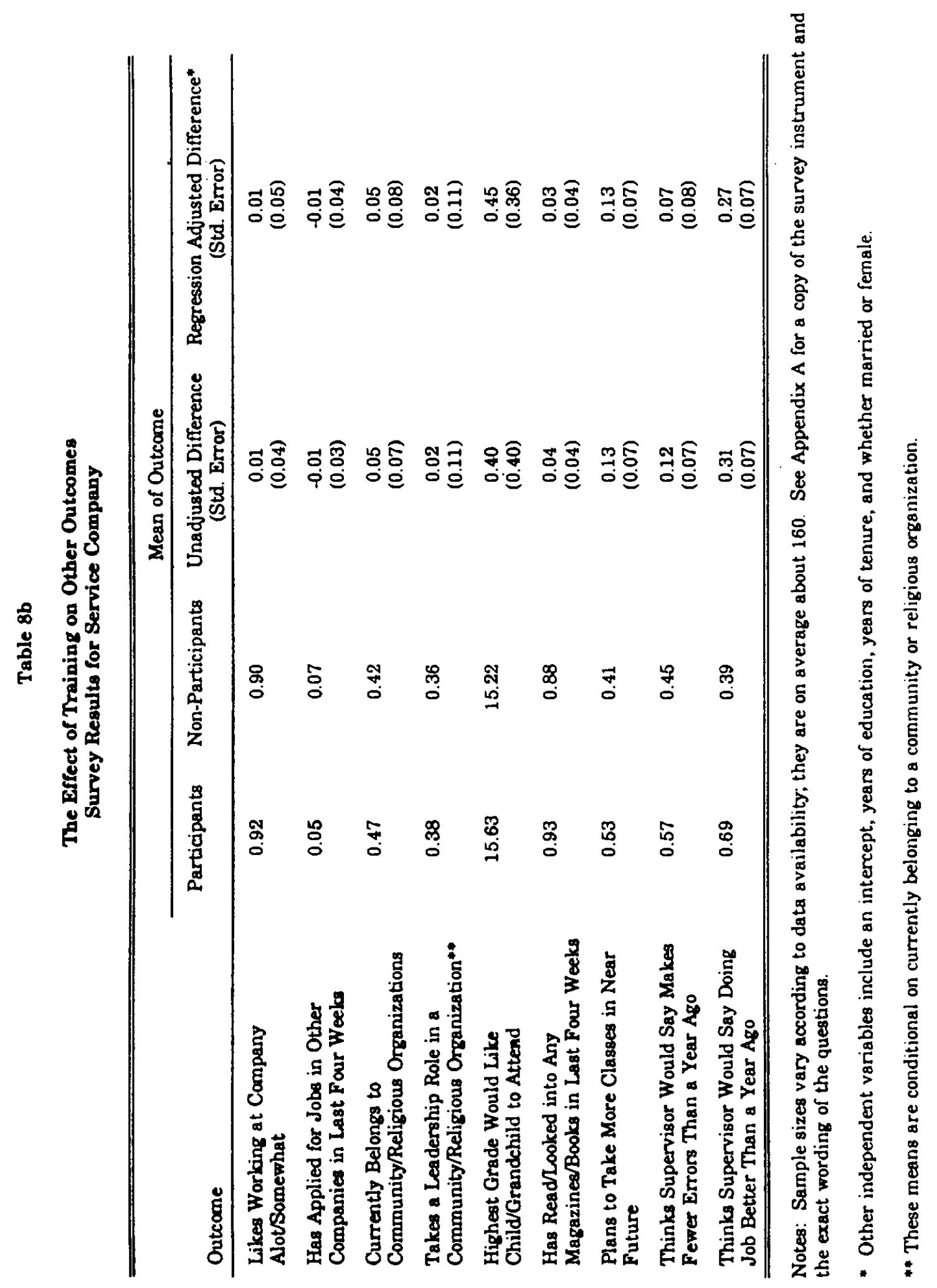


31 percentage points more likely to report that their supervisor would say they are doing a better job currently than a year ago (before training). Whether these results signify that trainees' actual job performance has improved, or are just a reflection of improved self-esteem from training is an open question.

\section{v. Conclusion}

We conclude by crudely comparing the likely benefits and costs of the training program. Earlier we noted that the total cost of training (direct expenses and release time) for these programs was approximately 4 percent of the average trainee's annual compensation. How large is the return on training that is required to justify this investment? If we assume that completed job tenure is 20 years (twice average incomplete tenure spells), and use a 3 percent real discount rate, then the training program would need to generate a 0.275 percent annual return to cover its costs in present value.

How do our estimated benefits compare to the required rate of return? The most direct monetary estimates we have of the return to the training is the wage growth associated with participating in training. For the manufacturing company these estimates are between 0.4 and 0.6 percent for occupational classes, whereas for the service company the estimates are typically insignificantly different from zero (as well as from 0.275 percent). On the other hand, it is possible that the social return to the training is higher than the measured private wage growth because workers may not capture all (or even most) of the proceeds of their increased productivity from job training. There are several additional caveats that are necessary to qualify this favorable interpretation. Perhaps most importantly, one could easily question whether the higher wage growth we document for trainees at the manufacturing company is causally linked to the training program. In addition, we do not know whether 
the short term 0.4-0.6 percent wage growth associated with occupational training is an effect that lasts 20 years. And although we plan to follow-up the long-term effects of the training program, we have no way of following workers who leave the companies. This may be a significant limitation because Topel and Ward (1992) document that significant wage gains are associated with mobility.

If the payoff from training dissipates before 20 years, or if the estimated effect is biased upward, the benefits of job training would be smaller than we estimated. Nevertheless, we interpret our results as suggesting that the measured return to investment is probably in the same ballpark as the required rate of return. Naturally, more analysis would be useful to determine if the training were cost effective. 


\section{References}

Bartel, Ann P. "Productivity Gains from the Implementation of Employee Training Programs." National Bureau of Economic Research Working Paper, No. 3893.

Bartel, Ann P. "Training, Wage Growth and Job Performance: Evidence from a Company Database." Journal of Labor Economics, forthcoming.

Bassi, Laurie J. "Workplace Education for Hourly Workers." Journal of Policy Analysis and Management 13, no. 4 (1994): 55-75.

Bishop, John H. "Job Performance, Turnover, and Wage Growth." Journal of Labor Economics, 8, no.3 (1990): 363-386.

Bloom, Howard S., Larry L. Orr, George Cave, et. al. "The National JTPA Study: Title IIA Impacts on Earnings and Employment at 18 Months," Abt. Associates, January 1993.

Brown, Charles. "Empirical Evidence on Private Training," in Research in Labor Economics, R. Ehrenberg, editor. Greenwich, Connecticut: JAI Press, 1990.

Burtless, G. "Meeting the Skill Demands of the New Economy." Washington, D.C.: Brookings Institution, 1993;

Heckman, James, Rebecca L Roselius, and Jeffrey A. Smith. "U.S. Education and Training Policy: A Re-evaluation of the Underlying Assumptions Behind the 'New Consensus'." Center for Social Program Evaluation Working Paper \#CSP\#94-1, December, 1993.

Holzer, Harry J., Richard N. Block, Marcus Cheatham, and Jack H. Knott. "Are Training Subsidies for Firms Effective? The Michigan Experience." Industrial and Labor Relations Review, forthcoming.

LaLonde, Robert J. "The Earnings Impact of the U.S. Employment and Training Programs," unpublished manuscript, University of Chicago, January, 1992.

Lillard Lee A. and Hong W. Tan. Private Sector Training: Who Gets It and What Are Its Effects?. Los Angeles: The Rand Corporation, 1986.

Lynch, Lisa. "Private-Sector Training and the Earnings of Young Workers." The American Economic Review 82,no. 1 (1992): 299-312.

Parsons, Donald O. "The Firm's Decision to Train," in Research in Labor Economics, R. Ehrenberg, editor. Greenwich, Connecticut: JAI Press, 1990.

Topel, Robert H. and Michael P. Ward. "Job Mobility and the Careers of Young Men." Quarterly Journal of Economics 107, no.2 (1992): 439-480. 
</ref_section> 
Appendix Table 1

Cross Section Wage Equations

Service and Manufacturing Companies

Dependent Variable: Log Hourly Wage in 1992 or 1994

\begin{tabular}{|c|c|c|c|c|}
\hline & \multicolumn{2}{|c|}{ Service Company } & \multicolumn{2}{|c|}{ Manufacturing Company } \\
\hline & 1992 & 1994 & 1992 & 1994 \\
\hline $\begin{array}{l}\text { Age } \\
(+10)\end{array}$ & $\begin{array}{c}0.073 \\
(0.069)\end{array}$ & $\begin{array}{c}0.073 \\
(0.069)\end{array}$ & $\begin{array}{c}0.025 \\
(0.023)\end{array}$ & $\begin{array}{c}0.041 \\
(0.022)\end{array}$ \\
\hline $\begin{array}{l}\text { Age } \\
(+1000)\end{array}$ & $\begin{array}{l}-0.146 \\
(0.074)\end{array}$ & $\begin{array}{l}-0.153 \\
(0.073)\end{array}$ & $\begin{array}{l}-0.027 \\
(0.027)\end{array}$ & $\begin{array}{l}-0.047 \\
(0.026)\end{array}$ \\
\hline $\begin{array}{l}\text { Tenure (Yrs) } \\
(+10)\end{array}$ & $\begin{array}{c}0.184 \\
(0.038)\end{array}$ & $\begin{array}{c}0.169 \\
(0.038)\end{array}$ & $\begin{array}{c}0.033 \\
(0.014)\end{array}$ & $\begin{array}{c}0.026 \\
(0.015)\end{array}$ \\
\hline $\begin{array}{l}\text { Tenure } \\
(+1000)\end{array}$ & $\begin{array}{l}-0.163 \\
(0.076)\end{array}$ & $\begin{array}{l}-0.123 \\
(0.074)\end{array}$ & $\begin{array}{l}-0.050 \\
(0.051)\end{array}$ & $\begin{array}{l}-0.027 \\
(0.049)\end{array}$ \\
\hline Female & $\begin{array}{l}-0.103 \\
(0.030)\end{array}$ & $\begin{array}{l}-0.103 \\
(0.029)\end{array}$ & $\begin{array}{l}-0.037 \\
(0.007)\end{array}$ & $\begin{array}{l}-0.032 \\
(0.007)\end{array}$ \\
\hline Nonwhite & $\begin{array}{l}-0.129 \\
(0.031)\end{array}$ & $\begin{array}{l}-0.141 \\
(0.031)\end{array}$ & $\begin{array}{l}-0.036 \\
(0.005)\end{array}$ & $\begin{array}{l}-0.034 \\
(0.005)\end{array}$ \\
\hline Ever-married & $\begin{array}{c}0.052 \\
(0.029)\end{array}$ & $\begin{array}{c}0.053 \\
(0.029)\end{array}$ & $\begin{array}{c}0.015 \\
(0.006)\end{array}$ & $\begin{array}{c}0.013 \\
(0.005)\end{array}$ \\
\hline $\begin{array}{l}\text { Education } \\
\text { (Yrs) }\end{array}$ & $\begin{array}{c}0.045 \\
(0.010)\end{array}$ & $\begin{array}{c}0.044 \\
(0.010)\end{array}$ & $\begin{array}{c}0.009 \\
(0.002)\end{array}$ & $\begin{array}{c}0.008 \\
(0.002)\end{array}$ \\
\hline Constant & $\begin{array}{c}1.715 \\
(0.192)\end{array}$ & $\begin{array}{c}1.788 \\
(0.193)\end{array}$ & $\begin{array}{c}2.343 \\
(0.049)\end{array}$ & $\begin{array}{c}2.341 \\
(0.049)\end{array}$ \\
\hline $\mathbf{R}^{2}$ & 0.373 & 0.395 & 0.233 & 0.213 \\
\hline No. of Observations & 220 & 220 & 503 & 503 \\
\hline
\end{tabular}

Notes: Standard errors are in parentheses. The regression for the service company also included a dummy variable indicating whether education is missing. 
Appendir A

Company Survey Instrument

*Note: Question 12,12a and 15 were not asked at the manufacturing company. 


\section{Skills Classes Survey}

Thank you for taking the time to complete this questionnaire. The purpose of this questionnaire is to learn more about the effectiveness of the Skills clasges and to design a better program in the future. Even if you did not take any Skills classes, your cooperation is very important and greatly appreciated. While we hope that you will fully answer all questions, even your partial response would be helpful.

All information that you provide will be strictly confidential and will not be disclosed or released to others for any purpose. The data will only be used for statistical purposes. We ask you to provide your name to help us process the data. Under no circumstances will anyone at this company or from the Skills program know your identity or be able to link your response to your name.

\section{How to show your answers}

Most questions have answer categories. For these questions, just circle the number in front of the answer category that fits you best. Some questions ask you to circle more than one number.

For example:

My favorite season is (Circle one)
1 Spring
2 Summer
3 Fall
4 Winter

A few questions ask for write-in answers.

If you have any questions or concerns, do not. hesitate to talk with one of the survey representatives. We would be happy to help you.

Your Name

Please turn the page and begin. 
SECTION I: Tell us a couple of things about yourself.

1. What is your current marital status? (Circle one)

2. Is English your first language?

(Circle one)

3. How do you usually get to work?

(Circle as many as apply)

4. How long have you been working for your present employer?

(Fill-in or circle the $X$ )

5. In addition to your job at this company, do you have any other jobs that you do after hours or on weekends? (Circle one)
1 Never-married

2 Married

3 Widowed

4 Divorced/Separated

1 Yes

2 No

3 Not sure

1 I drive myself (car or motorycle)

2 Someone else drives me

3 Bus (or other public transportation)

4 Walk or bicycle

5 Other

SECTION II: The questions in this section are about your attitudes towards your job.

6. How much do you like working at this company?

(Circle one)

1 A lot

2 Somewhat

3 A little

4 Not too much

5 Not sure

7. Have you applied for any jobs in other companies in the last four weeks? (Circle one)

8. Do you think that your supervisor would say that you make... $\quad$ (Circle one)

$1 Y$ es

2 No

3 Not sure

years (if mere than 1 year) months (if less than 1 year)

$1 Y_{6}$

2 No

3 Not sure

1 fewer errors than a year ago

2 about the same number of errors as a year ago

3 not sure

9. Do you think that your supervisor would say that you are doing your job.... (Circle one)

1 better than you did a year ago

2 about the same as a year ago

3 not sure 
SECTION III: We'd now like to ask you a few questions about you and the people you work with regularly. If you would answer differently for different people, give us your overall impression.

None of your co-workers or supervisors will see your answers.

10. If one or more of the people in your work area took Skills classes, did you ever have to work harder while they were in class? (Circle one)

11. Compared with 1992 (over a year ago, before the classes began) does your group work together better as a team because of the Skills classes? (Circle one)

\author{
1 Yes \\ 2 No \\ 3 Not sure \\ 4 I was in class. to \\ 5 None of them took classes
}

12. Who at this company do you work with regularly? (If you can think of more than one person, just pick one of them.)

(Fill in a name or circle the $X$ )
1 Yes
2 No
3 Not sure
4 None of un took classes

12a. Did he/she take any Skills classes? (Circle one)

Name

$X$ Can't think of anyone

1 Yes

2 No

3 Not sure

The next three questions are about pay. Remember that the questionnaire is confidential.

13. How much do you usually earn per hour? (regular pay not overtime)

(Fill in or circle the $\mathrm{X}$ )

14. Which of the following is true about the people you work with more regularly?

(Circle one)

15. How much do you think the co-worker you mentioned in Question 12 now earns per hour? (Fill in or circle the $\mathrm{X}$ )
$\$$ Not sure hour

1 Most of us know each other's pay

2 Some of us know, most of us guess

3 Most us do not know

4 Not sure

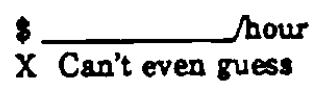


SECTION IV: The questions in this section are about your family and your activities outside of work.

16. How far in school do you want your oldest child or grandchild (aged 18 or younger) to go?

(Circle one)

17. Do you currently belong to any community or religious organizations?

(Circle one)

17a. If yes, do you take a leadership role in any of them? (Circle one)

18. In the past four weeks, did you happen to read or look into any magazines or books?

(Circle one)

19. How far in school have you gone? (Circle the highest level you bave attained)

20. In the near future, do you plan to take, or are you currently taking, any high school, college, or vocational school classes?

(Circle one)
1 At least some bigh school

2 Graduate from high school

3 Attend vocational, trade, or business school after bigh school

4 At least some community or four-year college

5 Graduate from a community or four-year college

6 Attend graduate school

7 I have no child/grandchild that age

1 Yes

2 No

3 I did, but I don't any more

4 I would, but I don't have the time

5 Not sure

$1 Y e$

2 No

3 Not sure

$1 Y e$

2 No

3 Not sure

1 I did not graduated from high school

2 I have a high achool diploma or equivalency derree (GED)

3 I attended a vocational, trade, or business school

4 I attended a community or four-year college, but did not graduate

5 I graduated from a community college (AA)

6 I graduated from a four-year college (BA)

7 I have attended graduate school

8 Not Sure

1 YeA

2 No

3 Not sure 
SECTION V: The questions in this section are about the Skills classes.

21. Did you take any Skillo classes? (Circle one)
1 Yes (Please skip to Question 25)

2 No (Please continue)

Please answer the following questions if you did not take any Shills classes.

(If you did take any Skills classes, please skcip to Question 25)

22. Why did you not take the Shills class(es)? (Circle as many as apply)
1 Not interested

2 Didn't need it

3 Couldn't get off the aoor

4 Other (please specify below)
23. If this company were to continue to offer classes, would you consider taking a class? (Circle one)
1 Yes

2 No

3 Not sure

23a. If yes, what classes would you like to see offered? (Please answer in the space below)

23b. If pe why not?

(Please answer in the space below)

24. Is there anything about the classes that is not covered above and that you would like us to know about? (Please use the opace below.)

You have finished. Thank you very much for your time; we greatly appreciate your belp. Please put the survey in the boc. 
Please answer the following questions if you did take one or more Skills classes. In the following questions. you may refer to any or all of the classes you bave taken. We're primarily interested in your overall impression of the class(es).

25. Why did you take the Skills class(es)? (Circie as many as apply.)
1 I wanted to improve/update my skills in general

2 I needed to know more about a subject

3 My supervisor made me do it

4 I wanted to prepare for the GED

5 I wanted to improve my English

6 I wanted to get off the floor

7 I wanted to learn enough to belp my childrea/grandchildren at bome

8 Other (please specify below)
26. Were you more likely to come to work on the days you had a class?

(Circle one)

27. Do the skills you learned in class belp you with your current job and/or would they help with future jobs at this company? (Circle one)

27a. Which skills are belpful and how do they help? (Please answer in the space below.)

28. If this company were to continue to provide classea, would you recommend them to a friend? (Circle one)
1 Yes
2 No
3 Not sure 
29. If this company were to continue to provide classes, would you consider taking more classes? (Circle one)

29a. If yes, what classes would you like to see offered? (Please answer in the space below)

29b. If no, why not?

(Please answer in the space below)

30. All things considered, how useful do you think the Skills classes are to you now on your job? (Circle one)

31. Is there anything about the classes that is not covered above and that yqu would like us to know about? (Please use the space below.)
1 Yes

2 No

3 Not sure
1 Useful: I learned some things and am able to use them

2 Somewhat useful: There were a few good ideas, but some wasted time as well

3 Not too useful: I could have gotten along fine without it

4 Not sure

You have finished. Thank you very much for your time; we greatly appreciate your help. Please put the survey in the box. 